\title{
Bonuser og opsjoner ved familierettslig skifte
}

Kandidatnummer: 630

Leveringsfrist: 25 . april

Til sammen 14285 ord

24.04.2008 


\section{Innholdsfortegnelse}

$1 \quad$ INNLEDNING $\quad 1$

$\begin{array}{lll}1.1 & \text { Rettskilder og metode } & 2\end{array}$

$\begin{array}{lll}1.2 & \text { Problemstilling } & 2\end{array}$

$\underline{2}$ OPSJONER OG BONUSER $\quad 3$

$\begin{array}{lll}2.1 & \text { Bonuser } & 3\end{array}$

2.2 Opsjoner 44

$\begin{array}{lll}2.3 & \text { Definisjoner } & 7\end{array}$

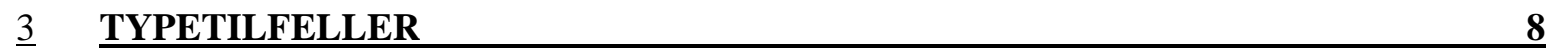

$\begin{array}{lll}3.1 & \text { Opsjons- og bonuseksemplet } & 8\end{array}$

$\begin{array}{lll}3.2 & \text { Meglereksemplet. } & 9\end{array}$

$\begin{array}{lll}3.3 & \text { Bonusbankeksemplet } & 10\end{array}$

$\begin{array}{lll}3.4 & \text { Andre incentivordninger } & 10\end{array}$

$4 \quad$ SKJEVDELINGSREGELEN I EL. § $59 \quad 12$

$\begin{array}{lll}4.1 & \text { Hovedregel og unntaksregel. } & 12\end{array}$

$\begin{array}{lll}4.2 & \text { Bakgrunnen for skjevdelingsregelen } & 15\end{array}$

$\begin{array}{lll}4.3 & \text { Opsjoner og bonuser i forhold til el § } 59 & 16\end{array}$

4.3.1 Hvordan beregne den forholdsmessige delen 23 
$\begin{array}{lll}5.1 & \text { Regelen om skjæringstidspunktet } & 31\end{array}$

$5.2 \quad$ Begrunnelsen for el § 60

$5.3 \quad$ Opsjoner og bonuser i forhold til el § 60

5.3.1 Hvordan beregne en eventuell forholdsmessig del $\quad 44$

\begin{tabular}{ll} 
LITTERATURLISTE & 45 \\
\hline
\end{tabular} 


\section{$1 \quad$ Innledning}

Ved et familierettslig skifteoppgjør vil en måtte avgjøre hvilke verdier som er gjenstand for deling. Det vil her både kunne oppstå spørsmål om hva hver ektefelle eier og hvilke midler som kan kreves skjevdelt. Lønn i form av bonus og opsjonsavtaler blir stadig vanligere. Slike avtaler varer gjerne over lengre tid og er betinget av at den ansatte som avtalen gjelder for, må arbeide i firmaet i en viss tid. Når en slik betinget avtale både foreligger før og under ekteskapet vil dette kunne medføre juridiske problemer i forhold til om disse kan kreves skjevdelt etter ekteskapsloven (heretter forkortet el) § 59. Videre vil det ved en slik betinget avtale som foreligger under og etter ekteskapet skape komplikasjoner i forhold til hva som er gjenstand for deling og hva som ikke er det etter el $\S 60$.

De spørsmålene oppgaven drøfter vil som oftest gjelde familierettslige skifter. Ved skjevdelingstilfeller er dette fordi skjevdeling må kreves av ektefellen etter el § 59. Når det gjelder el § 60 vil bonusen eller opsjonen kreve at ektefellene fortsetter i arbeidet sitt etter skjæringstidspunktet. Det vil følgelig bli få arveskifter hvor disse problemene dukker opp. 


\subsection{Rettskilder og metode}

Spørsmålene oppgaven stiller er ikke avgjort av Høyesterett. Loven er naturlig nok hovedrettskilden i denne oppgaven, og da særlig Ekteskapsloven $§ \S 59$ og 60. Ordlyden i de overfor nevnte paragrafene er en viktig rettskilde for tolkningen av reglene om skjevdeling og skjæringstidspunktet i forhold til betingede fordringer. I tillegg vil formålet til lovbestemmelsene kunne ha betydning for hvordan lovteksten tolkes. Selv om det ikke foreligger noen høyesterettsdommer som avgjør de problemstillingene som oppgaven tar opp vil rettspraksis like fullt kunne ha generell overføringsverdi. Juridisk teori og reelle hensyn vil også være rettskilder av betydning i denne oppgaven.

Når det gjelder disponeringen av oppgaven, er det først redegjort generelt for den aktuelle lovbestemmelsen og så utformet noen eksempler hvor jeg har argumentert for og imot de forskjellige løsningsalternativene. Jeg har redegjort for argumenter som taler for de ulike løsningene og vektlagt dem, før jeg til slutt har konkludert med hva jeg anser som gjeldende rett.

\subsection{Problemstilling}

De juridiske problemstillingene jeg vil ta opp er ikke så avhengig av hvilken type bonus eller opsjonsordning som er valgt, men er avhengig av bindingstiden til disse ordningene. Bindingstid er den perioden en ansatt må være i firmaet for å få krav på bonusen eller opsjonen. Når opsjoner og bonuser har bindingstid eller andre betingelser som medfører at det er uvisst om de vil ha noen verdi for innehaveren, sier vi at de er betingede fordringer. Dette vil kunne medføre problemer både ved hva som kan kreves skjevdelt etter el § 59 og i forhold hva som er opptjent ved skjæringstidspunktet (el § 60). 
Jeg håper oppgaven kan ha generell overføringsverdi for betingede fordringer, selv om den kun tar for seg bonuser og opsjoner.

\section{Opsjoner og bonuser}

Både bonuser og opsjoner brukes i stadig større grad som en del av lønninger i privat sektor i Norge. Slike bonus- og opsjonsordninger kalles også incentivordninger. En incentivordning er en lønnsordning som skal motivere ansatte til å yte mer. Det er ofte ledere og ansatte i sentrale stillinger som har bonus- og opsjonsavtaler, men det forekommer også ordninger for større grupper av de ansatte. Andelen heltidsansatte i privat sektor med bonus steg fra 18 prosent i 1997 til omtrent 28 prosent i $2005 .^{1}$

\subsection{Bonuser}

Bonus er en av flere former for bevegelig lønn som kommer til utbetaling dersom bestemte resultater er nådd. ${ }^{2}$ Definisjonen må for avhandlingens del, avgrenses mot akkordlønn, som håndverkere og en del andre yrkesgrupper kan ha. Bonusutbetalingene vil i de fleste tilfeller komme i tillegg til fast avtalt lønn, og utgjør normalt en mindre andel av de samlede lønnsutbetalingene en ansatt får i løpet av et år. De bonusavtalene som oppgaven drøfter vil ha bindingstid. Bindingstid innebærer for den ansatte at vedkommende må bli værende i jobben ut bindingstiden, for å få rett på bonusen, eventuelt opsjonen om det er opsjoner det gjelder. Dette gjør skillet mellom akkordlønn og bonus

\footnotetext{
${ }^{1}$ Statistisk sentralbyrå (2007) s. 3
}

${ }^{2}$ NHO (2006) s. 2 
tydeligere, siden akkordlønn ikke vil være betinget av at en blir værende i jobben, slik som bindingstiden forutsetter..

Det skilles ofte mellom virksomhetsbaserte og individuelle bonusordninger. Det finnes også kombinasjoner av disse. Ved en virksomhetsbasert bonusordning vil bonusen utmåles på grunnlag av virksomhetens overskudd. Individuelle bonusordninger utmåles som ordet tilsier, etter hva hver enkelt presterer. En individuell bonusordning vil for eksempel kunne utmåles fra hvor stort salg en ansatt har hatt i bedriften. Eller fra en generell vurdering av hvor god innsats en ansatt har gjort. Som vi senere vil se (under punkt 3.1), vil spørsmålet om bonusordningen er individuell eller virksomhetsbasert ikke ha noen betydning for hvordan den skal behandles på skiftet.

Formålet med bonusordninger er å virke motiverende for de ansatte og dermed skape økonomiske resultater for bedriften. ${ }^{3}$ Noen bonusordninger er i tillegg utformet slik at bonusutbetalingen dras ut over flere år med tilsvarende bindingstid. Disse vil i større grad enn bonusordninger med kort bindingstid, gjøre det økonomisk ugunstig for den ansatte å slutte i selskapet, fordi man vil miste bonusen man holder på å opparbeide seg om man slutter. I tillegg vil ekstreme svingninger i bonusutbetalingen til en viss grad bli unngått, fordi utbetalingen foregår over lengre tid. Noe som igjen gir selskapet en fordel ved at de slipper negativ publisitet fra media om store utbetalinger. ${ }^{4}$

\subsection{Opsjoner}

En opsjon kan defineres som en kontrakt som gir innehaveren en rett, men ingen plikt, til å kjøpe eller selge en formuesgjenstand til en pris som er fastsatt på forhånd, i løpet av en bestemt tidsperiode i fremtiden. ${ }^{5}$ Et typisk eksempel er at opsjonen gir en rett til å kjøpe en aksje til en bestemt pris på et bestemt tidspunkt (for eksempel om et år), så vil

\footnotetext{
${ }^{3}$ NHO (2006) s. 3 flg.

${ }^{4}$ Bråtan (2006) s. 69

${ }^{5}$ Bøhren (2006)
} 
aksjeverdien avgjøre om det vil bli lønnsomt å innløse opsjonen. Med å innløse menes det at man nyttiggjør seg opsjonen. I de tilfellene hvor aksjekursen stiger, vil det være lønnsomt å innløse opsjonen, fordi en da får mulighet til å kjøpe aksjene til underpris. Hvis opsjonen må innløses på en bestemt dato, kalles den europeisk. Kan den derimot innløses i en periode, kaller vi den for en amerikansk opsjon. Hvilken opsjonstype som er benyttet, vil ikke påvirke den familierettslige drøftelsen.

Når opsjoner gis som en del av lønn til ansatte, kalles de ansatteopsjoner eller lønnsopsjoner. Disse har i praksis lik betydning. Ved lønnsopsjoner får en vanligvis rett til å kjøpe en andel av aksjene i firmaet man jobber i til aksjekursen som firmaets aksjer har ved inngåelsen av opsjonsavtalene. Hvor vanlig slike opsjoner er i firmaer, varier avhengig av hvilken næring det gjelder. I Norge har lønnsopsjoner vært spesielt vanlig i IT-bransjen. For firmaer i oppstartfasen er også opsjoner en populær løsning. Dette er fordi disse firmaene ikke har så god likviditet. Ved å lønne ansatte gjennom opsjoner, får firmaene en utsettelse av lønnsutbetalingene. Opsjoner kan gi mindre bedrifter muligheten til å konkurrere med større bedrifter om den beste arbeidskraften, fordi opsjoner kan kompensere for større bedrifters fordel med god likviditet. God likviditet kan brukes til å lokke ansatte med høye lønninger. I tillegg gir opsjoner lønn som er i samsvar med hvor bra det går med firmaet. Nyetablerte firmaer vil derfor gjerne finne det hensiktsmessig å lønne ansatte gjennom opsjonsavtaler. Opsjoner har særlig kommet fra 90-tallet og utover. Det er tre hovedbegrunnelser for å gi lønn i form av opsjoner. ${ }^{6}$ De skal motivere de ansette, tiltrekke folk og binde ansatte til selskapet.

Det er vanlig å utstede opsjoner med bindingstid. Bindingstid innebærer at opsjonen ikke kan innløses før bindingstiden er over. Det sentrale ved bindingstid når opsjonen brukes som lønn og altså det relevante i denne oppgaven, er at om den ansatte slutter i jobben før bindingstiden er utløpt, vil dette innebære at vedkommende mister retten til opsjonen. Her i oppgaven må som nevnt bindingstid forstås slik at den sikter til perioden en ansatt må jobbe i et firma for å få krav på opsjonen eller bonusen.

Ved opsjoner kan man skille mellom syntetiske og ekte opsjoner. En ekte opsjon gir innehaveren av den rett til å kjøpe noe (ofte aksjer) til en forhåndsbestemt pris i et fastsatt

\footnotetext{
${ }^{6}$ Steingrimsen (2006)
} 
tidsrom. I våre tilfeller med lønnsopsjoner vil det være retten til å kjøpe aksjer i firmaet hvor man jobber. Aksjene kan enten eksistere fra før, eller det kan bli utstedt nye aksjer om man velger å benytte seg av opsjonen.

En syntetisk opsjon gir eieren rett til et kontant vederlag som tilsvarer differansen på inngangsprisen og aksjekursen på det tidspunktet opsjonen kan innløses. Inngangsprisen vil ved lønnsopsjoner være aksjekursen på det tidspunktet opsjonsavtalen begynner å løpe om ikke annet er bestemt. Om aksjekursen ved oppstarten av opsjonsavtalen ligger på 100 kroner og den 3 år senere ligger på 200 kroner, vil den ansatte få utbetalt 100 kroner.

Det kan diskuteres om syntetiske opsjoner skal sees på som bonus eller opsjon. Dette er fordi en syntetisk opsjon i praksis bare vil innebære en bonus. som beregnes ut fra hvor mye aksjekursen har steget i opsjonsperioden, slik som virksomhetsbaserte bonusordninger kan gjøre. Likevel vil det iblant kunne være en forskjell, fordi man i en del tilfeller vil kunne bestemme når opsjonen skal innløses innen for en gitt tidsperiode. Bonuser vil til sammenlikning som oftest utbetales på et bestemt tidspunkt, men både bonuser og opsjoner kan utformes både på den ene og den andre måten. Utformingen av incentivordninger er i stadig utvikling. Det sentrale ved disse ordningene for denne oppgaven er som nevnt bindingstiden. 


\subsection{Definisjoner}

Jeg definerer ord og uttrykk første gang de brukes i oppgaven, men jeg har likevel funnet det hensiktsmessig å ha et punkt hvor man kan slå opp de bonus- og opsjonsuttrykkene som er mest sentrale i oppgaven.

Bindingstiden er den tiden en ansatt må bli værende i jobben for å ha krav på bonusen eller opsjonen.

Med opptjeningstid mener jeg den perioden den ansatte kan påvirke verdien av bonusen eller opsjonen. Det må ved denne definisjonen avgrenses mot bindingstid. Under bindingstiden kan opsjonen eller bonusen falle bort og følgelig miste sin verdi, men slikt verdiforandring omfavnes ikke av uttrykket opptjeningstid i denne oppgaven

Innløsningsperioden er den perioden en kan velge å benytte seg av en opsjon. 


\section{Typetilfeller}

Bonuser og opsjoner varierer i utforming, og det kommer stadig nye varianter av disse. Jeg har satt opp noen typetilfeller av bonuser og opsjoner, som jeg kommer til å benytte meg av for å illustrere de juridiske problemene som skal drøftes.

\subsection{Opsjons- og bonuseksemplet}

Bonuser har ofte like lang opptjeningstid og bindingstid. Disse bonusene vil ved skifte måtte behandles likt som de opsjonstilfellene som har lik opptjeningstid og bindingstid. Med opptjeningstid mener jeg perioden den ansatte kan påvirke verdien av bonusen eller opsjonen. Det må ved denne definisjonen avgrenses mot bindingstid. Under bindingstiden kan opsjonen eller bonusen falle bort og følgelig miste sin verdi, men slik verdiforandring omfavnes ikke av uttrykket opptjeningstid i denne oppgaven. I Opsjons- og bonuseksemplet vil det som nevnt ikke være noen forskjell på bindingstid og opptjeningstid, men som vi skal se av eksemplet under i punkt 3.2, kan lengden på disse være forskjellig. For bonuser vil ofte bindingstiden være et år, mens opsjoner kan ha bindingstid på flere år.

Hvis vi tar utgangspunkt i en opsjonsavtale som starter i januar 2004 med bindingstid til januar 2007, eller om vi ser på en bonusordning som starter opp i 01.012007 og har bindingstid til 31.12.2007, vil de juridiske problemene i forhold til skifte bli de samme. At opsjonen er syntetisk eller ekte, amerikansk eller europeisk har ikke noen betydning for hvordan de skal behandles på skifte. Det som er karakteristisk for typetilfellet 
opsjons- og bonuseksemplet, er at bindingstiden er like lang som opptjeningstiden for disse eksemplene. Senere i oppgaven vil jeg bruke en opsjon med tre års bindingstid som eksempel, men det kunne altså likså godt vært en bonus med et års bindingstid.

Det er ingen krav som stilles for å kunne benytte opsjonen eller bonusen utover bindingstiden, men hvis innsatsen som gjøres under opptjeningstiden er god, vil det kunne øke verdien av bonusen eller opsjonen. For opsjoner og virksomhetsbaserte bonusordninger vil innsatsen kunne føre til at aksjekursene stiger, og dermed vil opsjonen/bonusen bli mer verdt. For individuelle bonusordninger vil innsatsen i seg selv kunne være nok til at bonusutbetalingen øker.

Eksemplet med tre års bindingstid er hentet fra Orkla og Norske skog. Innløsningsperioden etter disse tre årene var forskjellig. Om innløsningsperioden vil få betydning for skiftet, vil dette kommenteres der hvor spørsmålet oppstår. Innløsningsperioden er som nevnt den perioden den ansatte kan benytte seg av opsjonen.

\subsection{Meglereksemplet.}

Meglere har ofte en bonusordning hvor bindingstiden varer lengre enn opptjeningstiden. Det er dette som skiller meglereksemplet fra å være som opsjons og bonuseksemplet ovenfor, og det vil være interessant å se om denne forskjellen har noen betydning for skiftet. Opptjeningsperioden kan for eksempel være fra 1. januar 2007 til 31. desember 2007, mens det kreves at megleren blir værende i jobben fram til 1. mai 2008. I dette eksemplet kommer forskjellen på opptjeningstid og bindingstid tydelig fram. I opptjeningstiden vil bonusen kunne variere i verdi, i mai kan verdien være 50000 kroner, i juli kan den være 30000 og i oktober kan den være 70 000. Når opptjeningstiden er over den 31. desember 2007, vil bonusen ha en bestemt verdi, som bare kan bortfalle om bindingstiden eventuelt ikke overholdes. 


\subsection{Bonusbankeksemplet}

Noen bedrifter har en bonusordning som kalles bonusbank. Bonusbanken fungerer slik at opptjent bonus overføres til en individuell bonusbank, hvoretter $1 / 3$ av saldoen i bonusbanken utbetales hvert år. Denne bonusen beregnes etter virksomhetens resultat(virksomhetsbasert bonusordning). Går bedriften med underskudd et år, blir bonusen som tilføres bonusbankkontoen negativ. I de tilfellene hvor saldoene på bonusbanken er negativ vil det ikke foretas noen bonusbetaling, verken utbetaling eller innbetaling. Hvis den ansatte slutter i firmaet, vil vedkommende miste retten til en eventuell positiv saldo i bonusbanken.

For eksempel vil den ansatte ved års slutt etter å ha jobbet i 2004 få 150.000 kroner i bonus, som bokføres på en bonuskonto. En tredje del av denne bonusen vil da bli utbetalt i januar 2005 (50.000). Det resterende beløpet (100.000) vil bli værende på bonusbankkontoen. Et år senere vil bonusen for 2005 bokføres bonusbankkontoen eksempelvis 20.000. Saldoen vil da være 120.000, og en tredje del av saldoen (40.000) vil da bli utbetalt i januar 2006. Om bonusen for 2006 da for eksempel blir -20.000, vil saldoen være 60.000 og bonusutbetalingen i januar 2007 vil bli 20.000 .

Bonusbankeksempelet er hentet fra Orkla og Kongsberg Gruppen.

\subsection{Andre incentivordninger}

Det finnes en rekke andre incentivordninger jeg ikke har tatt med i denne fremstillingen. Dette skyldes først og fremst at jeg har knyttet oppgaven min til de

problemene som oppstår når slike ordninger er betingede, og det er da ikke nødvendig å benytte flere eksempler for å få fram de juridiske problemstillingene. Men tanken er at 
drøftelsene skal kunne ha overføringsverdi både til andre incentivordninger som er betinget, men også til en viss grad til behandlingen av betingede fordringer generelt. 


\section{$4 \quad$ Skjevdelingsregelen i el. § 59}

\subsection{Hovedregel og unntaksregel.}

Hovedregelen i norsk rett er at ektefellenes formuer skal deles likt mellom de to (el $\S 58$ ). Det er bare felleseiemidler som skal deles. Felleseiemidler er de midlene ektefellene eier ved ekteskapsinngåelsen, og det som erverves fram til skjæringstidspunktet. ${ }^{7}$ Motsetningen til felleseiemidler er særeiemidler, som ikke skal deles. Særeie kan enten avtales ektefellene i mellom eller være bestemt av en giver eller arvelater. Ved utmåling av delingsmidlene skal der gjøres fradrag for gjeld etter el § 58. Man sier da at det er netto formue som er gjenstand for deling. Selv om midler ikke er gjenstand for deling pga unntakene i el $\S \S 59$ og 61 vil de fortsatt være felleseiemidler.

Ektefellene har tilnærmet avtalefrihet ved delingsoppgjøret etter el § 65, noe som bl.a. gir mulighet til å avtale seg bort fra unntaksreglene i el §§ 59 og 61. Men å gå nærmere inn på dette faller utenfor min drøftelse, og jeg vil i den fremtidige drøftelsen gå ut ifra at det ikke foreligger noen avtale mellom ektefellene angående dette.

El § 59 er et unntak fra el § 58, som kan gi ektefellen(e) rett til å holde en del midler utenfor deling (skjevdeling). Bestemmelsen lyder: "Verdien av formue som klart kan føres tilbake til midler som en ektefelle hadde da ekteskapet ble inngått eller senere har ervervet ved arv, eller ved gave fra andre enn ektefellen, kan kreves holdt utenfor delingen.”

For at skjevdeling skal kunne foretas er det et krav at ektefellen "hadde" verdiene som kreves skjevdelt, da ekteskapet ble inngått, eventuelt at midlene senere er ervervet ved arv eller gave. I redegjørelsen for bonuser og opsjoner er det kravet om at ektefellen hadde

\footnotetext{
${ }^{7}$ Lødrup (2005) s. 112
} 
midlene ved ekteskapsinngåelsen som er interessant å drøfte. Lønn i form av bonuser og opsjoner vil ikke være ervervet ved arv eller gave.

Det er videre et krav om at ektefellen kan vise at verdier som kreves skjevdelt, er i behold ved skjæringstidspunktet og stammer fra midler ektefellen hadde før ekteskapet ble inngått. Skjæringstidspunktet er som oftest den datoen ektefellene bryter samlivet, og denne datoen er avgjørende for hva som skal deles. Forandringer i ektefellers formuesforhold etter skjæringstidspunket skal ikke vektlegges (se nærmere redegjørelse for skjæringstidspunktet under drøftelsen om el § 60, punkt 5).

Det er ikke noe krav om at formuesgjenstandene som forelå ved ekteskapets inngåelse må foreligge ved skjæringstidspunktet for at de skal kunne kreves skjevdelt, men det vil gjøre det lettere for ektefellen å vise at midlene var opptjent før ekteskapet. Hvis en ektefelle har investert det som var ervervet før ekteskapet i en annen formuesgjenstand som er i behold, vil fortsatt retten til skjevdeling være der. Dette er i teorien ${ }^{8}$ blitt fremstilt som et ombyttingsprinsipp. Poenget er i hvert fall at midlene ikke må være oppbrukt. Jeg forutsetter i oppgaven at midlene kan "føres tilbake til" de aktuelle verdiene som kreves skjevdelt. Hvis ikke dette kravet er oppfylt er det ingen grunn til å drøfte om ektefellene "hadde" verdiene ved ekteskapet, og det er spørsmålet om ektefellene "hadde" verdiene ved ekteskapets inngåelse jeg ønsker å drøfte.

Ektefellen som krever noe skjevdelt, har bevisbyrden for at midlene som kreves skjevdelt, er ervervet før ekteskapets inngåelse. Gjennom ordlyden ”klart kan føres tilbake til” kan det utledes at bevisbyrden krever mer enn vanlig sannsynlighets overvekt for å kunne kreve skjevdeling. Men å redegjøre nærmere for hvor streng bevisbedømmelsen skal være favnes ikke av min problemstilling. ${ }^{9}$

Videre må en ektefelle kreve at verdiene skjevdeles for at de skal holdes utenfor deling. Regelen er en verdiregel, noe som kommer fram i forarbeidene. ${ }^{10}$ Dette innebærer at den gir rett til å holde verdiene av skjevdelingsmidlene utenfor deling, men ikke de faktiske gjenstandene som kreves skjevdelt. Dette vil ofte ikke få så stor betydning da ektefellen ofte vil ha rett til å beholde sine eiendeler etter el § 66 .

\footnotetext{
${ }^{8}$ Lødrup (2005) s.261

${ }^{9}$ Se nærmere Lødrup (2005) s. 263 flg.

${ }^{10}$ Ot prp nr 28 (1990-1991) s. 121
} 
I tilfeller hvor midlene som kreves skjevdelt har økt i verdi under ekteskapet, vil årsaken til økningen avgjøre om verdiøkningen også er gjenstand for skjevdeling. Kravet for å kunne kreve noe skjevdelt etter el § 59 er at midlene som kreves skjevdelt skal kunne føres tilbake til midler som ektefellen hadde før ekteskapet, eventuelt som er ervervet ved arv eller gave under ekteskapet. Dette kravet gjelder også for verdiøkningen. Hvis verdiøkningen stammer fra skjevdelingsmidler, vil altså verdiøkningen også kunne skjevdeles. Det samme gjelder om gjenstanden har steget i verdi, fordi den generelle verdien av slike gjenstander har økt. Om verdiøkningen derimot skyldes en av ektefellenes innsats under ekteskapet, vil verdiøkningen ikke være gjenstand for skjevdeling. Denne tolkningen av loven støttes av formålet med delingsreglene. Formålet med reglene er at når innsatsen for å erverve midler er foretatt under ekteskapet, skal midlene være gjenstand for likedeling. Når innsatsen derimot er foretatt før ekteskapets inngåelse, bør midlene kunne kreves skjevdelt. ${ }^{11}$ Verdiøkningen som skyldes den ene eller begge ektefellenes innsats under ekteskapet, skal være gjenstand for likedeling. ${ }^{12}$

Videre kan det i verdiøkningstilfellene også vises til Rt-2001-1434 hvor Høyesterett siterer NOU 1987:30 s.83-84: ”Er eiendeler som skal skjevdeles gjenstand for verdiøkning ved ektefellen(e)s innsats under ekteskapet, vil verdiøkningen være gjenstand for likedeling. Det som skal skjevdeles er verdiene da ekteskapet ble inngått, ... Skyldes derimot verdistigningen innsats med midler som ellers er unntatt fra deling, tilfaller den selvsagt vedkommende ektefelle fullt ut. .... På tilsvarende måte stiller det seg med verdiøkning som skyldes den alminnelige prisstigning.”

\footnotetext{
${ }^{11}$ NOU $1987: 30$ s 83

${ }^{12}$ Lødrup (2005) s 266
} 


\subsection{Bakgrunnen for skjevdelingsregelen}

Begrunnelsene for likedelings- og skjevdelingsreglene bygger på de samme hensyn. Likedelingsregelen under forrige ekteskapslov var begrunnet slik: "Likedelingsregelens sterkeste begrunnelse er det fellesskap ekteskapet skaper i partenes økonomi og livsførsel.." ${ }^{13}$ Forarbeidene til ekteskapsloven viser at likedelingsregelen fortsatt er begrunnet med det fellesskapet av økonomisk og annet art som består mellom ektefellene. ${ }^{14}$ I tillegg gjør rettstekniske hensyn seg gjeldende. Likedelingsregelen medfører at en slipper å finne ut hvem som har ervervet hva, og hvem sine midler som har blitt forbrukt og spart. ${ }^{15}$ Videre er det også lagt vekt på at tilfeldigheter kan gjøre at den ene ektefellen har spart pengene den har opptjent under ekteskapet eventuelt brukt pengene på gjenstander som beholder sin økonomiske verdi, mens den andre har betalt forbruksvarer. ${ }^{16}$ Disse tilfeldighetene bør ikke ha betydning for hva hver ektefelle skal sitte igjen med etter ekteskapet.

Begrunnelsen for likedelingsregelen er som nevnt fellesskapet mellom ektefeller under ekteskapet. Det kan diskuteres om det er noen forskjell mellom fellesskapet i ekteskap og fellesskapet mellom samboere, men grensen er satt ved ekteskapsinngåelsen. I forarbeidene sies det følgende om midler som er ervervet før ekteskapet: ”Slike midler er ikke resultat av ektefellenes felles innsats under ekteskapet." 17 "Det er etter komiteens oppfatning ikke like rimelig at verdier som ikke er skapt gjennom fellesskapet, men brakt inn i ekteskapet av den ene part eller ervervet gjennom gave eller arv under ekteskapet skal gjøres til gjenstand for likedeling selv etter et langvarig samliv". ${ }^{18}$ Forarbeidene legger vekt

\footnotetext{
${ }^{13}$ Lødrup (1962) s. 29

${ }^{14}$ NOU $1987: 30$ s. 79

${ }^{15}$ Lødrup (2005) s. 231-232

${ }^{16}$ Ot. prp. 1990-1991 nr 28 s. 63

${ }^{17}$ Ot. prp. $1990-91$ nr 28 s. 63

${ }^{18}$ Innst. O. 71 (1990-91) s. 14
} 
på at det ikke er rimelig at formue som er ervervet før ekteskapet skal likedeles, særlig hvor ekteskapet er relativt kort og det er snakk om midler av et visst omfang. ${ }^{19}$

\subsection{Opsjoner og bonuser i forhold til el § 59}

Jeg vil benytte en del eksempler for å redegjøre for hvordan bonuser og opsjoner skal behandles ved skjevdelingskrav etter el § 59. De fleste av disse vil gjenkjennes som et av typetilfellene i kapittel 3. Eksemplene er utformet med tanke på at de skal kunne ha overføringsverdi til liknende incentivordninger. Vi kan først ta utgangspunkt i et eksempel hvor det ikke foreligger noen betingelser ved fordringen når ekteskapet inngås for å vise forskjellen på betingede og ikke betingede fordringer.

Bonusen er for eksempel opptjent i desember 2000 og bindingstiden er like lang som opptjeningstiden (desember 2000), men bonusen utbetales ikke før i mars 2001. Ektefellene inngår ekteskap i januar 2001. Dette eksemplet er som typetilfellet bonuser og opsjoner (punkt 3.1). Her vil hele bonusen være gjenstand for skjevdeling, selv om den ikke er utbetalt. Dette er fordi kravet om at ektefellen hadde midlene ved ekteskapsinngåelsen i el § 59 er oppfylt. Hvis ektefellen kan vise at disse midlene er i behold ved skjæringstidspunktet, noe som er et krav for å kunne kreve skjevdeling, vil disse midlene "kunne føres tilbake til midler ektefellen hadde ved ekteskapsinngåelsen" og følgelig kunne kreves skjevdelt etter el § 59. At bonusen ikke er utbetalt ved ekteskapsinngåelsen kan ikke være avgjørende så lenge ektefellen har en ubetinget rett på bonusen. Denne løsningen er også i tråd med formålet til delingsreglene om at midler som er opparbeidet under det fellesskapet ekteskapet innebærer skal likedeles, og at det som er opparbeidet før skal kunne kreves skjevdelt. I dette tilfellet vil bonusen i sin helhet være opptjent og det vil ikke hefte noen betingelser ved denne når ekteskapet inngås.

\footnotetext{
${ }^{19}$ Ot.prp. $1990-91$ nr 28 s. 63
} 
Ved enkelte opsjonsordninger som har en lengre innløsningsperiode (perioden eieren kan velge å benytte opsjonen i eller ikke), vil det her kunne oppstå et problem som ikke gjør seg gjeldende for bonuser. Vi kan ta utgangspunkt i et eksempel der opsjonens bindingstid varer frem til januar 2000, men innløsningsperioden varer frem til juni 2000. Dette eksemplet skiller seg litt ut ifra typetilfellet i punkt 3.1, fordi opptjeningsperioden i praksis vil vare frem til den ansatte velger å innløse opsjonen. Dermed vil opptjeningstiden være lengre enn bindingstiden, hvis ikke opsjonen innløses den dagen bindingstiden utløper. Uavhengig om opsjonen innløses i januar 2000 og ektefellen beholder aksjene til juni 2000, eller om opsjonen først innløses i juni 2000 bør dette ikke ha betydning for skjevdelingskravet. Midlene vil i like stor grad ervervet før og under ekteskapet. Hvis opsjonen stiger i verdi, eller om aksjene gjør det, påvirker ikke hva som er inntjent før og under ekteskapet. Dersom opptjeningsperioden fortsetter etter at bindingstiden er utløpt vil dette være verdiøkning av noe vedkommende allerede har.

Hvis eieren her for eksempel venter med å innløse opsjonen til juni 2000 og gifter seg i mars 2000, vil fortsatt opsjonen kunne kreves skjevdelt ved et eventuelt skifte. Spørsmålet blir om en eventuell verdiøkning fra mars 2000 til juni 2000 er gjenstand for skjevdeling?

Det som vil være avgjørende her, vil være om arbeidsinnsatsen ektefellen foretar i firmaet bidrar til prisstigningen. Hvis den gjør det, vil prisstigningen skyldes arbeid under ekteskapet og følgelig måtte være gjenstand for deling. Kommer en derimot til at ektefellens innsats ikke har noen betydning, vil verdiøkningen være en følge av markedssvingninger, og da vil opsjonen fullt og helt kunne føres tilbake til midler som forelå ved ekteskapsinngåelsen.

Vi kan da gå over til å se på eksempler hvor bonusen eller opsjonen er betinget ved ekteskapsinngåelsen og hvordan løsningen da vil være.

En person A hadde for eksempel en lønnsopsjonsordning som startet 1. januar 2000, og hvor bindingstiden varte fram til 1. januar 2003. Denne personen inngikk så ekteskap med person B 1. januar 2001. I 2008 skal ektefellene skille seg, og ektefelle A (samme som person A) krever å få skjevdelt opsjonsmidlene. Det forutsettes at ektefelle A kan bevise at 
han eller hun har midler som kan føres tilbake til det som kreves skjevdelt ved delingsoppgjøret. Eksemplet er igjen utledet fra typetilfellet om bonuser og opsjoner (punkt 3.1)

Hvordan vil da et krav om skjevdeling av opsjonen vurderes? En del av opsjonsmidlene vil her være opptjent fra 2000-2001 og altså kunne føres tilbake til verdier som ektefellen hadde før ekteskapet ble inngått, og en del vil være opptjent under ekteskapet. Spørsmålet blir da om hvor stor del av opsjonen som kan kreves skjevdelt.

Det er her tre mulige alternativer for hvordan disse tilfellene skal løses. Man kan beregne seg frem til en forholdsmessig del som tar hensyn til hvor stor del som er ervervet før og under ekteskapet. En kan også komme til at hele opsjonen er gjenstand for deling. Det tredje alternativet er at hele verdien kan kreves skjevdelt, men dette vil en ikke kunne komme til fordi ikke alle midlene kan føres tilbake til midler ektefellen hadde ved ekteskapsinngåelsen.

Vi må her ta utgangspunkt i lovens ordlyd for å avgjøre hvordan spørsmålet skal løses. For at midlene skal kunne kreves skjevdelt er det etter el § 59 et krav at ektefellen (A) hadde midlene (opsjonen), eventuelt en del av den, da ekteskapet ble inngått.

Hvis det er to år igjen av bindingstiden ved ekteskapsinngåelsen medfører dette at ektefelle A ikke hadde hele opsjonen ved ekteskapsinngåelsen. Opsjonsverdien kan variere fra dag til dag. Den verdiforandringen opsjonen vil ha etter ekteskapsinngåelsen vil være skapt under ekteskapet, fordi ektefellen må jobbe i firmaet for å få rett på opsjonen. I tillegg kan ektefellen påvirke en eventuell verdistigning i firmaet gjennom jobben som blir gjort i firmaet.

Om ordlyden taler for at en forholdsmessig del av opsjonen kan kreves skjevdelt, eller om den taler for at opsjonen ikke kan skjevdeles, kan diskuteres. Det kan på den ene siden anføres at ordlyden taler for at det bør gjøres en skjønnsmessig vurdering av skjevdelingskravet ved opsjonen, fordi ektefellen hadde opsjonen ved ekteskapsinngåelsen, selv om den ikke var ferdig opptjent. Da den ikke er ferdig opptjent, må det gjøres en forholdsmessig vurdering av hva ektefellen hadde ved ekteskapsinngåelsen.

Det kan argumenteres med at ordlyden taler mot at opsjonen er gjenstand for skjevdeling, ved å vise til at den var betinget da ekteskapet ble inngått (januar 2001). Hvis 
A hadde sluttet i jobben før januar 2003, ville ikke opsjonen hatt noen verdi. Dette vil tale mot at ektefelle A hadde opsjonen da ekteskapet ble inngått.

Ordlyden avgjør ikke om skjevdeling kan kreves for en forholdsmessig del av opsjonen, eller om hele opsjonen skal være gjenstand for deling. Ingen av løsningene kan sies å være i strid med ordlyden.

For å drøfte hva som er en riktig forståelse av el § 59 vil formålet ved regelen være et vesentlig moment. Forarbeidene viser at formålet med regelen er at verdier som er ervervet ved innsats som er foretatt før ekteskapet, skal kunne kreves skjevdelt og midler som er ervervet etter innsats under ekteskapet skal likedeles. ${ }^{20}$ Ektefelle A sin innsats i forhold til opsjonen er fordelt over tre år, hvor det ene året er før ekteskapets inngåelse og to år er i løpet av ekteskapet. Dette er et betydelig argument for at det må gjøres en forholdsmessig vurdering, fordi en del av innsatsen er foretatt under ekteskapet og en del er foretatt før.

Mot at opsjonen skal kunne kreves skjevdelt for en forholdsholdsmessig del, er tvilen om opsjonen har noen faktisk verdi på det tidspunktet ekteskapet ble inngått et argument. Siden opsjonen ikke kan overdras og ikke kan innløses, kan det diskuteres hvorvidt den har en verdi. Dersom det er omsetningsverdien som skal legges til grunn så er jo verdien null, siden den ikke kan omsettes. Men det er jo mulig å beregne seg frem til en verdi opsjonen vil ha for ektefellen. Dette kan gjøres ved å se på kursen til opsjonen den dagen ekteskapet ble inngått, og å ta hensyn til sannsynligheten for at opsjonen faller bort. Opsjonen vil ofte kunne anses for å ha en verdi for ektefellen, selv om den ikke kan omsettes på det aktuelle tidspunktet.

El § 60 er avgjørende for hvilken formue som er gjenstand for deling ved skifte, og setter sluttstreken for hvilke erverv som skal være med på et skifte. El § 59 regulerer hva ektefellene hadde ved ekteskapsinngåelsen, og el § 60 regulerer hva ektefellene hadde ved skjæringstidspunktet. Skjæringstidspunktet er den dagen da sluttstreken for hva som skal være med på skiftet settes. Det kan argumenteres med at siden paragrafene bestemmer hva ektefellene "hadde" når ekteskapet inngås og ved skjæringstidspunktet, så burde hva de "hadde” avgjøres på samme måte. Etter el § 60 vil en ikke kunne si at en ektefelle "hadde"

\footnotetext{
${ }^{20}$ Ot.prp. $1990-91$ nr 28 s. 63
} 
en opsjon som i dette eksemplet ved skjæringstidspunktet. Er det her noen overføringsverdi fra el $\S 60$ ?

Likheten i ordlyden mellom el § 59 og el § 60 stopper ved ordet "hadde”. Uttrykket "hadde” som loven her bruker, er en såpass generell term at likheten i ordlyden neppe blir et vektig argument for at ordet "hadde” skal avgjøres på samme måte i de to paragrafene.

Selv om ikke likheten i ordlyden mellom el $\S \S 59$ og 60 i dette tilfellet vil tillegges nevneverdig vekt, vil fortsatt sammenhengen mellom el § 59 og el § 60 kunne få betydning som et tolkningsmoment. Begge reglene er bestemmende for hva som skal være gjenstand for deling. Det kan derfor anføres at hva som skal sees opptjent ved ekteskapsinngåelsen (skjevdelingsspørsmålet i el § 59) bør avgjøres på samme måte som hvor mye som var opptjent ved samlivsbruddet (skjæringstidspunktet etter el § 60). Begge paragrafene avgjør hva som skal være gjenstand for deling og hva som ikke skal det.

Hvis det er slik at ektefellen ikke "hadde” en opsjon etter el § 60, fordi bindingstiden ikke var utløpt når samlivet ble brutt, kan en argumentere for at det vil det være uheldig at ektefellen hadde den etter delingsreglene i el § 59. Hvorfor skal det sies at man hadde en betinget opsjon ved ekteskapsinngåelsen når man ikke hadde den når samlivet brytes?

Men det er også en forskjell mellom reglene som vil kunne begrunne en ulik løsning for de to paragrafene. At en fordring som er betinget ved skjæringstidspunktet holdes helt utenfor deling, skyldes at den ved skjæringstidspunktet ikke har noen sikker verdi. Det vil ofte være vanskelig å omsette den, og det er vanskelig å fastsette en kommende verdi på den. Det som skjer etter skjæringstidspunktet er delingsoppgjøret uvedkommende og kan i utgangspunktet ikke vektlegges. Derfor kan forskjellen i tolkningen av el $\S 59$ og 60 være velbegrunnet. Forskjellen på de to paragrafene medfører i hvert fall at overføringsverdien fra el § 60 får mindre betydning.

Hvis det er skjevdeling som er spørsmålet, så er det klart at deler av opsjonen ble opptjent før ekteskapet ble inngått. Uten denne perioden ville opsjonen ha vært mindre verdt. Sånn sett vil det være urimelig om opsjonen ikke skulle kunne skjevdeles i det hele tatt, når en del er opptjent før ekteskapet. Selv om man ikke har mulighet til å gjøre en 
vurdering av etterfølgende hendelser etter el § 60, bør ikke dette nødvendigvis gjøre at man skal la være å gjøre dette etter el $\S 59$.

Ved skifte vil det ofte være enklere å beregne seg frem til en forholdsmessig del for skjevdelingsgjenstandene enn for hva som har verdi på skjæringstidspunktet. Dette gjelder spesielt eksemplene med opsjonsavtaler med lang bindingstid som ikke nødvendigvis er utløpt ved skiftet.

Det er en annen forskjell på el $\S 59$ og 60 som gjør overføringsverdien fra el $\S 60$ til el § 59 mindre. Dette kan vises med følgende eksempel: Ektefelle A hadde for eksempel en 3-årig opsjonsavtale med en bindingstid som varer til januar 2010. Skjæringstidspunktet etter el § 60 er januar 2008. Hvis opsjonen da deles forholdsmessig, vil dette bli problematisk hvis opsjonen senere viser seg å ikke bli innløst fordi ektefelle A slutter i jobben. En tilsvarende situasjon ved skjevdeling vil derimot ikke være noe problem av den enkle grunn at om opsjonen ikke blir innløst, men i stedet faller bort, vil det ikke være noen midler som kan føres tilbake til opsjonen. Dette viser at hva ektefellene hadde ikke nødvendigvis bør avgjøres på samme måte etter el $\S \S 59$ og 60.

Vekten en kan tillegge overføringsverdien fra el § 60 er begrenset.

Et annet argument for at det bør foretas en forholdsmessig vurdering er at hvis man skulle komme til at hele opsjonen skal likedeles, kan dette føre til en uheldige terskeleffekt i enkelt sammenhenger. Dette ser vi om vi setter eksemplet på spissen: Hvis Ektefelle A sin lønnsopsjon har en bindingstid som strekker seg en uke ut i det inngått ekteskapet, vil det jo være svært urimelig om en opsjonsavtale på flere år ikke skulle kunne kreves skjevdelt, fordi ektefellen ikke ”hadde” den ved inngåelsen av ekteskapet. Når eksemplet settes såpass på spissen, ser vi også at en løsning om at ektefellen ikke kan kreve skjevdeling for en slik opsjon, står i enda sterkere motsetning til formålet til delingsreglene enn ved tidligere eksempler. En regel om at betingede fordringer ikke skal kunne kreves skjevdelt vil kunne være uheldig ved enkelte tilfeller.

Hvis regelen skal være at opsjonen ikke kan kreves skjevdelt om ikke bindingstiden er utløpt ved ekteskapsinngåelsen, kan det diskuteres om det bør være rom for unntak ved de tilfellene hvor bindingstiden utløper kort tid etter ekteskapsinngåelsen. El § 59 3.ledd åpner for at en ektefelle kan gis rett til å kreve likedelingsmidler skjevdelt om sterke 
grunner taler for det. Dette vil i en viss grad kunne svekke terskeleffekthensynet i avsnittet over, fordi det i tilfeller hvor det er kort tid igjen av bindingstiden kan gjøres unntak. Problemet med en slik løsning er at tvistområdet bare vil flyttes til tilfeller hvor det er litt mer av bindingstiden igjen. Før eller senere vil det settes en grense for hvor unntak kan gjøres. Derfor vil det skape et bedre resultat om det gjøres en forholdsmessig vurdering av skjevdelingskravet.

Hvis regelen er at fordringer som er betinget ved ekteskapsinngåelsen ikke kan kreves skjevdelt, men at det må gjøres unntak etter el § 59 3. ledd vil dette skape mer tilfeldige resultater enn om det er en forholdsmessig deling som må legges til grunn. Det vil bli et problem å avgjøre hvor kort tid inn i ekteskapet bindingstiden må løpe, for at det skal kunne gjøres unntak for regelen. Hvis det ikke kan gjøres unntak etter el § 59 3. ledd, vil som nevnt dette også kunne skape uheldige resultater. Uansett om en skal kunne gjøre unntak for at opsjonen ikke kan kreves skjevdelt, eller om en ikke kan gjøre unntak, vil begge løsningene kunne lede til uheldige situasjoner.

Dette vil være et argument for at en bør kunne kreve en forholdsmessig del av den betingede opsjonen eller bonusen skjevdelt, fordi denne regelen generelt vil gi like tilfeller likt resultat uavhengig av hvilken situasjon som foreligger. Samtlige andre regler vil kunne medføre uheldige utfall i enkelte situasjoner.

Jeg har funnet forarbeidenes uttalelser om at begrunnelsen for skjevdelingsreglene er om innsatsen for å erverve noe er foretatt før eller under ekteskapet som avgjørende. Dermed har jeg kommet til at det må gjøres en forholdsmessigvurdering av hvor stor del som kan kreves skjevdelt. Denne løsningen vil gi de mest rettferdige resultatene uavhengig situasjon, noe som også har blitt tillagt vekt. Hvordan skjevdelingsvurderingen skal foretas er drøftet nedenfor.

Resultatet ville blitt det samme som i drøftelsen ovenfor om det gjaldt en bonus istedenfor en opsjon. Dette er fordi det er bindingstiden som er avgjørende for når bonusen er ervervet, og resultatet vil da bli det samme som i ovenfor nevnte drøftelse. Dette er uavhengig om bindingstiden og opptjeningstiden er like lang eller om bindingstiden er lengre enn opptjeningstiden. Hvis bindingstiden er lengre enn opptjeningstiden, vil en være 
utenfor typetilfellet i punk 3.1. Det vil i så fall være et eksempel som hører hjemme under typetilfellet i punkt 3.2. Her vil det fortsatt være bindingstiden som avgjør hvor lang tid det er brukt på å erverve bonusen. Derfor vil den samme drøftelsen gjelder for dette eksemplet også.

Hvis en opsjon har lengre opptjeningstid enn bindingstid, vil ektefellen ha opsjonen når bindingstiden er utløpt. Dersom opsjonen øker i verdi under opptjeningsperioden etter at bindingstiden er utløpt, vil denne delen bli behandlet etter reglene om verdiøkning som jeg har fremstilt tidligere. Derfor vil også drøftelsen av slike tilfeller avgjøres av bindingstiden, og følgelig er opsjonsdrøftelsen ovenfor relevant for slike tilfeller også. Så får en først drøfte hvor stor del av bindingstiden som løp før og under ekteskapet, og så drøfte opptjeningsperioden som et verdistigningstilfelle. Et slikt tilfellet likner på typetilfellet i punkt 3.1. Det kan diskuteres om dette tilfellet i det hele tatt skiller seg fra typetilfellet. Uavhengig om opsjonen stiger i verdi før den innløses, eller om man innløser opsjonen, og aksjene man har kjøpt gjennom opsjonen stiger i verdi, vil tilfellene behandles likt ved et skifte.

Det kan imidlertid stilles spørsmål om det vil bli forskjell ved beregningen av skjevdelingskravet, noe jeg skal komme tilbake til nedenfor.

\subsubsection{Hvordan beregne den forholdsmessige delen}

Hvordan den forholdsmessige delen som kan kreves skjevdelt skal beregnes kan variere avhengig av hvilket av eksemplene som skal drøftes.

Hvis vi bruker en bonus hvor bindingstiden og opptjeningstiden er like lang som eksempel, vil skjevdelingskravet vanligvis måtte avgjøres etter en fordeling av hvor lang opptjeningstiden var før og etter inngåelsen av ekteskapet. Vi kan eksempelvis si at ektefelle A hadde en bonus i år 2000 som ga 200000 kroner. Hvis ekteskapet da ble inngått

31. mars, må en fjerdedel av bonusen kunne kreves skjevdelt ved et eventuelt skifte, gitt at midlene er i behold. I disse tilfellene vil det ofte være vanskelig eller umulig å gjøre en 
verdivurdering av bonusen ved ekteskapsinngåelsen, fordi den i de fleste tilfeller blir oppregnet ved slutten av året. Derfor er eneste mulige løsning å gjøre en forholdsmessig vurdering av hva som kan kreves skjevdelt, utregnet etter lengden på opptjeningstiden før og etter ekteskapsinngåelsen.

Hvis vi tar utgangspunkt i en opsjon, kan det spørres om det er verdien ved ekteskapsinngåelsen som skal legges til grunn ved den forholdsmessige beregningen, eller om skjevdelingskravet skal beregnes ut fra bindingstiden på opsjonen. Opsjonen hadde for eksempel hatt en innløsningsverdi på 100000 kroner om den kunne vært innløst ved inngåelsen av ekteskapet. På dette tidspunktet er 2/3 av bindingstiden utløpt. Et år senere når den innløses har opsjonen en verdi på 120000 kroner. Skal da de 120000 kronene deles på tre år slik at ektefellen kan kreve 80000 kroner skjevdelt for de to årene før ekteskapet? Eller kan ektefellen kreve verdien ved ekteskapsinngåelsen (100 000 kroner) skjevdelt?

Vi må her ta utgangspunkt i lovteksten. El § 59 sier at midler ektefellen hadde før ekteskapet kan kreves skjevdelt, gitt at ektefellen kan vise at de er i behold. Det kan diskuteres om ordlyden legger noen føringer for om skjevdelingskravet skal beregnes etter opsjonens verdi ved ekteskapsinngåelsen, eller om det er hvor lenge bindingstiden har vart før og etter ekteskapsinngåelsen som skal være avgjørende for skjevdelingskravet. Etter ordlyden er det de verdier ektefellen "hadde" ved ekteskapsinngåelsen som kan kreves skjevdelt. Ved ekteskapsinngåelsen var verdien av opsjonen 100 000. Det kan derfor anføres at å utmåle skjevdelingskravet etter opsjonens verdi ved ekteskapsinngåelsen er mest forenlig med ordlyden. Samtidig kan det anføres at ektefellen "hadde" 2/3 av opsjonen fordi det var så mye av bindingstiden som var utløpt og følgelig hadde ektefellen ervervet 2/3 av opsjonen ved ekteskapsinngåelsen. Slik jeg ser det verken favoriserer eller utelukker ordlyden noen av løsningene.

Formålet med regelen vil her kunne være et viktig moment. Skjevdelingsregelens formål er at erverv som stammer fra innsats foretatt før ekteskapet, skal kunne kreves skjevdelt. At opsjonen er avhengig av at ektefellen jobber i selskapet ut bindingstiden for at den skal få verdi, taler for å la tidsperiodene før og etter ekteskapsinngåelsen avgjøre hvor 
mye av opsjonen som er opparbeidet før og etter ekteskapets inngåelse. Den siste dagen av bindingstiden er like viktig som den dagen opsjonen øker mest i verdi. Slik sett kan det argumenteres for at ektefellens innsats gjenspeiles i perioden vedkommende har jobbet der og ikke når verdiøkningen skjedde.

Mot dette taler derimot det at ektefellen selv kan være med å påvirke hvor mye opsjonen stiger fra år til år. Derfor vil den arbeidsinnsatsen ektefellen legger ned før og under ekteskapet gjenspeiles i verdien av opsjonen. Formålet med regelen er jo nemlig det at midler som kan føres tilbake til den innsatsen som er foretatt før ekteskapsinngåelsen skal kunne skjevdeles. En eventuell innvending mot dette kan være at ektefellen kan ha nedlagt like stor innsats under hele opsjonsperioden, men ha vært uheldig med kurssvingningene slik at opsjonen ikke økte i verdi under denne perioden. Dette kan igjen motargumenteres med at det er hva man har ervervet ved innsatsen som er avgjørende, ikke hvor stor innsatsen er i seg selv.

Et argument for at det er opptjeningsperioden som bør være avgjørende for skjevdelingskravet, er at dette er løsningen for bonuser (se ovenfor). Siden bonus- og opsjonsordninger glir over i hverandre, vil det være en fordel at reglene er like for begge to, slik at det ikke oppstår tvister i grensetilfellene. Det vil ellers kunne bli unødige forskjeller på tilfeller som er relativt like, fordi det ene blir ansett for å være en opsjon og det andre en bonus, selv om begge incentivordningene er en krysning av bonuser og opsjoner.

Jeg har under tvil kommet til at det er hvor lenge bindingstiden har vart før og etter ekteskapsinngåelsen som vil avgjøre hvor stor del som kan kreves skjevdelt.

Det kan spørres om resultatet vil være annerledes i de tilfeller hvor bonusverdien er opptjent, men bindingstiden fortsatt løper når ekteskapet inngås. For eksempel at bonusen var opptjent i 2000, men bindingstiden varte til 15.mai 2001. Da må vedkommende bli værende i jobben frem til bindingstiden utløper for å få utbetalt bonusen. Ektefellene inngår eksempelvis ekteskapet 1. mars. Dette eksemplet er utledet fra meglereksemplet (punkt 3.2) Skal da hele bonusen kunne kreves skjevdelt ved et eventuelt skifte siden den er opptjent før ekteskapet, eller må det gjøres en forholdsmessig vurdering slik at det gjøres fratrekk i skjevdelingskravet for perioden etter ekteskapsinngåelsen? 
El § 59 sier som nevnt at det er midler ektefellen hadde ved ekteskapsinngåelsen som er gjenstand for skjevdeling. Ordlyden kan ikke tillegges vekt i noen retning for forståelsen av hvordan fordelingen skal gjøres. Igjen vil formålet med regelen kunne være avgjørende for hvordan en forholdsmessig vurdering skal foretas. Det er et springende punkt om innsatsen for ervervelsen er foretatt før eller etter ekteskapsinngåelsen. I dette tilfellet kreves det en innsats fram til 15. mai 2001 for å ha rett på bonusen. Selv om den ansatte skulle være sykmeldt, ha ferie, eller liknende må vedkommende likevel bli ansett for å gjøre en innsats ved å være ansatt. Det vil kunne begrunnes med at det ferie og sykmelding er en del av jobbtilværelsen. Så lenge man er i en ansatt i et firma, gir det den ansatte en del plikter, noe som gjør at en kan si at det er en innsats i seg selv å være ansatt et sted. Dette taler for at det er hvor stor del av bindingstiden som har vært før og etter ekteskapsinngåelsen som er avgjørende for utmålingen av skjevdelingskravet. Formålet med regelen vil her være avgjørende for hvordan skjevdelingskravet skal utmåles, slik at bonuser hvor bindingstiden er lengre enn opptjeningsperioden må avgjøres etter hvor lang tid av bindingstiden som løp før og etter ekteskapsinngåelsen.

Som vi kan se av de tre eksemplene vi har sett på ovenfor, vil bindingstiden være avgjørende for hvor stor del som kan kreves skjevdelt i alle de tre tilfellene. Disse løsningene er forankret i at bindingstiden reflekterer innsatsen ektefellen har foretatt, og det er om innsatsen er foretatt før eller etter ekteskapsinngåelsen som begrunner regelen.

Hvis ektefelle A har en bonusbankavtale, vil spørsmålet om hvordan skjevdelingskravet skal utregnes kunne bli mer problematisk. Ved bonusbankeksemplet vil opptjent bonus overføres til en individuell bonusbank, hvoretter 1/3 av saldoen utbetales hvert år. Hvis den ansatte slutter i selskapet, vil eventuell positiv saldo i bonusbanken ikke bli utbetalt. Vi kan bruke som eksempel at ektefelle A hadde en bonusbankavtale hvor bonussaldoen ved ekteskapsinngåelsen (for eksempel 1. januar 2006) er 1500000 kroner. Ektefellene bryter samlivet 1. januar 2008. Hvor stor del kan da kreves skjevdelt? Eksemplet kan gjenkjennes som typetilfellet i punkt 3.3. Vi går ut ifra at ektefellen har verdier som kan føres tilbake til midlene som ble utbetalt fra bonusbanken. 
Hvor mye som skal skjevdeles kan utregnes ved at en først ser på de totale bonusutbetalingene i løpet av ekteskapet. Deretter regner man ut hvor store bonusutbetalingene hadde blitt om saldoen ved ekteskapsinngåelsen hadde vært lik null. Til slutt trekker man fra differansen på den totale bonusutbetalingen og den tenkte bonusutbetalingen. Dette kan tydeliggjøres ved et eksempel hvor ekteskapet er av kort varighet, men det vil gjøre seg like gjeldende i et langt ekteskap. Ektefellene inngikk ekteskap i januar 2006 og brøt samlivet i februar 2008. Ved ekteskapsinngåelsen hadde ektefelle a en bonusbanksaldo pålydende 1500000 kroner. Både overføringen til bonuskontoen fra firmaet og utbetalingene til ektefelle A foregår i januar hvert år. I år 2007 ble det først tilført 300000 til kontoen slik at saldoen lød på 1800000 før 1/3 ble utbetalt (600 000). Saldoen var da 1200 000. I år 2008 ble 300000 tilført igjen slik at saldoen lød på 1500000 før 1/3 (500 000)ble utbetalt, slik at det var igjen 1000 000. Her ser vi at A sin utbetalte bonus i løpet av ekteskapet er 1100000 (500 $000+600$ 000). Hvis A ikke hadde hatt bonussaldoen på 1500000 da ekteskapet ble inngått ville A for det første året fått 1/3 av 300000 (100 000) og for det andre året 1/3 av 500000 (bonusbanksaldoen (200 000 + 300 000)). Til sammen ville A fått ubetalt 266667 om A ikke hadde bonusbanksaldoen da de giftet seg. Altså vil skjevdelingskravet til A være på 1100 000266 667= 833333 kroner.

Løsningen ovenfor gir et riktig resultat for hvilke verdier som er ervervet ved innsats under ekteskapet, og hvilke midler som er ervervet ved innsats, før ekteskapet ble inngått. Dette er vesentlig siden begrunnelsen for delingsreglene er at det som er inntjent ved innsats under ekteskapet skal deles, og det som stammer fra innsats før ekteskapet skal kunne kreves skjevdelt.

Hvis det kun er enkelte av bonusutbetalingene ektefellen har igjen ved skjæringstidspunktet, fungerer metoden ovenfor fortsatt. Hvis vi for eksempel tenker oss at midlene i 2007 var brukt opp, men at ektefellene sitter igjen med 2008 midlene vil dette gi følgende resultat: utbetalingen i 2008 var 500 000, om A ikke hadde hatt saldoen ville utbetalingen vært 166 667. Dermed vil A kunne kreve skjevdelt 333333 kroner av bonusutbetalingen i 2008. 
Hvis det eventuelt skulle blitt anført at hele bonusbankens saldo ved ekteskapsinngåelsen skal kunne kreves skjevdelt, skal det kommenteres følgende. Denne løsningen vil ikke bli riktig, fordi ektefellen ikke vil ha utnyttet saldoen fullt ut ved samlivsbruddet. Som vi ser ovenfor, viser løsningen at 833333 kroner kan føres tilbake til midler ektefellen har anskaffet ved innsats før ekteskapet. Resten av bonusbanksaldoen som forelå ved skjæringstidspunktet, er ikke opptjent ennå og må drøftes etter § 60. Hvis ektefellen kunne kreve bonusutbetalingen frem til 1500000 kroner skjevdelt, ville dette medføre at ingenting av bonusen hadde blitt ansett for å være opptjent under ekteskapet, noe som ikke stemmer.

Særlig i USA, men også i Europa forekommer det en spesiell variant av lønnsopsjoner som gir rett til å kjøpe aksjer i firmaet hvor man jobber. Opsjonsavtalen i seg selv er akkurat som tidligere nevnte opsjonsavtaler, og kan for eksempel vare i tre år. Etter de tre årene kan den ansatte i et halvt års tid (innløsningsperioden) kjøpe et gitt antall aksjer til kursen aksjene hadde på det tidspunktet som opsjonsavtalen formelt sett ble inngått. Men ved denne varianten settes datoene for når opsjonen ble inngått sent i opsjonstiden. Datoene settes enten fram eller tilbake i tid. Målet med å utsette dateringen av opsjonen, er å sette datoene slik at en opsjon får størst mulig verdi. ${ }^{21}$ Sen datering av opsjoner kan være lovlig om det er godkjent av eierne av firmaet. Eksemplet med antedaterte opsjoner er en spesiell utgave av typetilfellet i punkt 3.1.

Antedatering kan gjøres på forskjellige måter. En kan for eksempel først sette en dato for opsjonen, som senere forandres til et tidspunkt som er økonomisk gunstig. Eller en kan la være å sette en dato i det hele tatt før det er godt er par år osv. Dette er ikke noen uttømmende liste over antedaterte opsjoner, men det som er hovedpunktet med antedaterte opsjoner er at datoen forandres eller settes sent i opsjonsperioden.

Behandlingen av antedaterte opsjoner kan gjøres lettere håndgripelig med et eksempel. Vi tenker oss at opsjonsavtalen reelt sett ble inngått i januar 2000 og kunne innløses fra januar 2003. I juli 2002 ser den ansatte og ledelsen at hvis opsjonen hadde vart fra juli 1999 til juli 2002, ville den ha hatt større verdi. Dette kan for eksempel skylde

\footnotetext{
${ }^{21}$ Wikipedia Options backdating
} 
kursen var lavere i juli 1999 enn i januar 2000. Derfor setter de datoene for opsjonen fra juli 1999 til juli 2002, slik at de får rett til å kjøpe aksjer til kursen de hadde i juli 2002. Slik får opsjonen større verdi enn om det var de reelle datoene som gjaldt. Dette påvirker opsjonsverdien, men det kan spørres om det også kan forandre hvor stor del som kan kreves skjevdelt.

En ansatt A har for eksempel en opsjonsavtale som blir inngått i januar 2000 og skal vare i tre år (januar 2003). Denne blir datert til å vare fra juli 1999 til juli 2002. Ansatt A har inngått ekteskap en gang i perioden fra juli 1999 til juli 2002. Vi kan si dette skjedde 1. januar 2002.

I et slikt tilfelle vil det bli spørsmål om det er perioden opsjonen er angitt å vare, eller perioden fra ektefelle A inngikk opsjonsavtalen (da uten datering) og tre år frem i tid (for vårt eksempel) som skal legges til grunn for utmålingen av skjevdelingskravet?

Loven krever som nevnt at ektefellen hadde midlene ved ekteskapets inngåelse. Det er her vanskelig å si hvilken av de to løsningsalternativene som går best i sammen med ordlyden. Hadde ektefelle A en forholdsmessig del utregnet etter den reelle tiden for opsjonen eller hadde ektefelle A den forholdsmessige delen utregnet etter de formelle datoene? Lovens ordlyd kan her ikke vektlegges i den ene eller den andre retningen.

Formålet med skjevdelingsregelen er at hvis innsatsen for ervervelse av midler er foretatt før ekteskapet er inngått, skal de kunne kreves skjevdelt. Dette vil kunne ha betydning. Innsatsen har vart fra ektefellen inngikk opsjonsavtalen og ut opsjonstiden. At den etterpå blir satt til å gjelde andre datoer vil ikke ha betydning for når innsatsen er foretatt, med mindre bindingstiden forandres av datosettingen til opsjonen. Dette taler for at det i eksemplet over vil være slik at 2/3 av opsjonsmidlene skal kunne kreves skjevdelt, og ikke 1/6 slik det kunne blitt om de antedaterte datoene skulle blitt tatt hensyns til. Dette avhenger av at de faktiske forholdene kan bevises. Det vil ofte kunne være vanskelig å bevise at en opsjon er tilbakedatert, men jeg går ut ifra at dette er mulig i denne drøftelsen.

Det kan som argument for at de forandrede opsjonsdatoene skal legges til grunn for skjevdelingskravet anføres at hvis ektefelle A jobbet i firmaet i perioden til de forandrede datoene, vil ektefellen kunne ha påvirket aksjeprisene ved sin innsats. Denne innsatsen vil i så fall bli belønnet gjennom ektefellens innløsning av opsjonen. Dette vil imidlertid kunne 
bli litt spekulativt. Det er vanskelig å finne ut hvor stor del av aksjekursen til et firma en ansatt klarer å påvirke ved sin arbeidsinnsats. Innsatsen ektefellen har gjort for å erverve opsjonen, vil som oftest bestå av å jobbe i firmaet de årene bindingstiden løper, slik at ektefellen får rett på opsjonen. Dermed vil den reelle datoen da opsjonsavtalen ble inngått være avgjørende så lenge denne kan bevises.

Et annet poeng som skal nevnes, er at hvis bindingstiden forandres av at den endelige datoen settes, vil dette få betydning for skjevdelingskravet. Vi kan tenke oss at ektefellen med opsjonsavtalen i eksemplet over blir enig med sin arbeidsgiver om at opsjonen skal kunne innløses i juli 2002. Hvis dette innebærer at bindingstiden faller bort, vil perioden etter juli 2002 ikke ha betydning for opparbeidelsen av opsjonen. I så fall vil perioden ektefellen har brukt på å erverve opsjonen være fra januar 2000 til juli 2002. Hvis ekteskapet fortsatt ble inngått i januar 2002, vil i så fall 4/5 kunne kreves skjevdelt. Dette er fordi det var så stor del av innsatsen for å opparbeide opsjonen som ble foretatt før ekteskapet ble inngått. 


\section{$5 \quad$ Skjæringstidspunktet i el. § 60}

\subsection{Regelen om skjæringstidspunktet}

El § 60 er avgjørende for hvilken formue som er gjenstand for deling ved skifte og setter sluttstreken for hvilke erverv som skal være med på et skifte. El § 60 første ledd lyder:

"Det som skal deles er den formuen hver ektefelle hadde

a. da begjæring om separasjon eller skilsmisse kom inn til fylkesmannen eller stevning med krav om separasjon eller skilsmisse kom inn til retten, eller da samlivet ble brutt dersom dette skjedde først”.

Skjæringstidspunktet er den dagen da sluttstreken for hva som skal være med på skiftet settes. Det er det ektefellene eier på skjæringstidspunktet som skal være gjenstand for deling. På samme måte er det etter el § 58 bare gjelden som ektefellene eventuelt måtte ha på dette tidspunktet som kan trekkes fra delingsmidlene. Dette kommer fram av el § 60 3. ledd. El § 60 2. ledd bestemmer at avkastning fra midler en av ektefellene eier ved skjæringstidspunktet ikke skal deles om avkastningen skjer etter skjæringstidspunktet.

Et sentralt punkt i den kommende drøftelsen er hvordan uttrykket "hadde” i el § 60 skal forstås. Det er formuen ektefellene "hadde” som skal deles. Med "hadde” menes det i el § 60 hva ektefellene eier. Det vil i tvilstilfeller måtte gjøres en skjønnsmessig vurdering for å avgjøre om det kan sies at en ektefelle "hadde” en gjenstand ved skjæringstidspunktet.

El § 60 stiller for øvrig opp noen andre alternative vilkår for når skjæringstidspunktet inntreffer enn de som står i første ledd, men disse får sjeldent anvendelse. Som oftest vil skjæringspunktet være da samlivet ble brutt. For at samlivet skal kunne anses som brutt, må partene være enig om å bryte samlivet, og det må i tillegg være 
ytre utslag som viser samlivsbruddet. ${ }^{22}$ Et typisk eksempel på dette er at ektefellene flytter fra hverandre. Siden det er samlivsbruddet som er det vanligste skjæringstidspunktet, bruker jeg begrepene samlivsbrudd og skjæringstidspunkt om hverandre senere i drøftelsen.

På samme måte som ved el § 59 har partene avtalefrihet til å avtale seg bort fra reglene i el § 60. Dette følger av regelen om alminnelig avtalefrihet ved delingsoppgjøret (el § 65).

Hvis ektefellen blir ansett for å ha en betinget fordring, vil det også kunne bli spørsmål om verdsettelsen av fordringen. Dette skal løses etter el § 69, men det må først avgjøres om fordringen foreligger ved skjæringstidspunktet, og dette må avgjøres etter el § 60. Hvis ikke ektefellen "hadde” opsjonen ved skjæringstidspunktet er det ikke behov for å finne verdien til opsjonen.

\subsection{Begrunnelsen for el § 60}

Begrunnelsen for at samlivsbruddet er avgjørende for skjæringstidspunktet er at det fellesskapet som er grunnlaget for likedelingsregelen ikke lenger foreligger. ${ }^{23}$

Ekteskapslovsutvalget uttaler: ”Det bør være det ektefellene eier når de går fra hverandre som skal deles, og den gjeld de da hadde som bør være relevant for adgangen til uttak av aktiva til dekning av gjeld. Etter at samlivet mellom partene er brutt, eksisterer ikke det fellesskap som eller danner grunnlaget for likedelingsregelen”. Derfor bør disposisjoner som foreligger etter samlivsbruddet holdes utenfor.

\footnotetext{
${ }^{22}$ Rt-1978-1327

${ }^{23}$ Ot. prp. (1990-91) nr 28 s. 74
} 


\subsection{Opsjoner og bonuser i forhold til el § 60}

En fordring som ikke kan realiseres før etter skjæringspunktet skal likevel være med på skiftet så lenge den er opptjent og det ikke hefter betingelser ved den når samlivet brytes. Dette er fordi det etter lovens ordlyd må sies at ektefellen "hadde” fordringen ved skjæringstidspunktet. Ektefellen har en ubetinget rett på fordringen ved skjæringstidspunkt, selv om den ikke har krav på å få den utbetalt før etter skjæringstidspunktet. Dette synet støttes også i teorien. ${ }^{24}$ Praktiske eksempler på dette kan være aksjeutbytte, pengekrav som ikke har forfalt, restskatt/få igjen på skatten osv.

Dette gjelder også bonuser og opsjoner hvor bindingstiden er utløpt når samlivet brytes, men hvor ektefellen ikke har fått bonusen, eller fått innløst opsjonen ennå. En av ektefellene har for eksempel en bonusordning hvor bindingstiden varer fra 1. januar 2007 til 31. desember 2007, men bonusen utbetales først i mars 2008. Ektefellene bryter samlivet i januar 2008 (eksemplet er basert på typetilfelle i punkt 3.1). I tilfeller som dette hvor bonusen eller opsjonen ikke er betinget, vil de altså være gjenstand for deling etter el § 60 første ledd.

Mer tvilsomt vil spørsmålet om deling være hvor det foreligger betingelser ved fordringer som ikke er oppfylt ved skjæringstidspunktet. For eksempel et lodd hvor trekningen ikke er foretatt, eller som i tilfellene som drøftes i denne oppgaven, hvor utbetalingen er betinget av at man blir værende i firmaet man jobber i til en gitt dato. Spørsmålet blir da om ektefellen ”hadde” bonusen eller opsjonen ved skjæringstidspunktet etter el $\S 60$.

Vi tar utgangspunkt i at ektefelle A har en lønnsopsjonsordning som begynner i januar 2007 med en bindingstid som varer frem til januar 2010, og ektefellene bryter samlivet i januar 2008. Det skal nevnes at dette eksemplet vil gjelde like mye for årlige bonusavtaler. Eksemplet kunne like gjerne vært at ektefelle A har en bonusavtale som varer fra 1. januar 2007 til 31. desember. Opptjeningsperioden og bindingstiden varer til 31.

\footnotetext{
${ }^{24}$ Holmøy (2001) s. 409
} 
desember 2007. Ektefellene bryter samlivet i juni 2007. Det er ingen grunn til at de to ovenfor nevnte eksemplene skal behandles forskjellig i forhold til el § 60. Om det gjelder bonus eller opsjoner gjør ingen forskjell. Det som er av betydning er betingelsen for at en skal få krav på opsjonen eller bonusen, nemlig å bli i jobben til bindingstiden til opsjonen eller bonusen er utløpt. Begge disse tilfellene er utledet fra typetilfellet i punkt 3.1, men jeg fortsetter som sagt med opsjonseksemplet.

Siden ikke hele opsjonen er ervervet ved skjæringstidspunktet, vil en ikke kunne komme til at ektefellen "hadde” hele opsjonen ved skjæringstidspunktet. De alternative løsningene blir da enten at ektefellen ikke "hadde" den betingede opsjonen ved skjæringstidspunktet, eller at ektefellen "hadde” en forholdsmessig del av opsjonen ved skjæringstidspunktet.

Lovteksten sier at det er den formue man "hadde” på skjæringstidspunktet som skal deles. Slik jeg ser det utelukker ikke ordlyden noen av de to alternativene. For at opsjonen skal kunne deles, kan det anføres at ektefellen hadde en betinget opsjon, og at den var betinget ikke medfører at ektefellen ikke "hadde" opsjonen. Mot at ektefellen "hadde" opsjonen kan det anføres at opsjonen nettopp var betinget og at det derfor ikke var sikkert at ektefellen vil kunne nyttiggjøre seg av den. Siden ordlyden ikke avgjør dette spørsmålet, vil de andre rettskildene få desto større betydning.

For bedre å forstå hvordan el § 60 skal tolkes, kan vi se på begrunnelsen for regelen. Det kommer riktig nok fram at skjæringstidspunktet bør være der formuesfellesskapet slutter, men ellers er det lite å hente her også. Det kan diskuteres om begrunnelsen for at skjæringstidspunktet skal være ved samlivsbruddet, kan brukes som et argument for en forholdsmessig deling, fordi det på samme måte som ved el § 59 er fellesskapet ektefellene opptrer i, som begrunner at samlivsbruddet skal være skjæringstidspunktet. At en del av innsatsen ved opsjonen er gjort under ekteskapet og en del er gjort etter, er et argument for en forholdsmessig deling av opsjonen ved skiftet. Dette argumentet svekkes av at det som skjer etter skjæringstidspunktet skal være skiftet uvedkommende. Derfor vil en ikke kunne ta hensyns til om opsjonen ble innløst eller ikke, og følgelig blir det vanskelig å gjøre en forholdsmessig deling som gjenspeiler hva som er opptjent under og etter ekteskapet. 
Det er ingen høyesterettsdom som avgjør spørsmålet om betingede opsjoner og bonuser ved skjæringstidspunktet. Det er derimot en lagmannrettsdom som behandler problemet. Saken gjelder en slik bonus som må likestilles med en opsjon i denne sammenhengen. Altså en bonus med like lang bindingstid og opptjeningstid.

LB-2005-72847 gjaldt formuesdeling mellom ektefeller etter samlivsbrudd. Her hadde B en bonusordning som hadde bindingstid som krevde at han jobbet i selskapet etter skjæringstidspunktet for at han skulle få rett på bonusen. Med andre ord var denne fordringen betinget. Lagmannsretten uttaler i den forbindelse følgende: ” Som nevnt av tingretten skal suspensivt betingede krav, der betingelsen eventuelt først inntrer etter skjæringstidspunktet, som hovedregel ikke tas med i delingsgrunnlaget. Da tingrettens dom ble avsagt, var det ikke klart om betingelsen om verdistigning var oppfylt, og tingretten avgjorde derfor saken etter denne hovedregelen. Det må nå som nevnt anses på det rene at B ikke hadde opptjent noen verdistigningsbonus på skjæringstidspunktet. Hadde han sluttet i selskapet da, ville han ikke fått noen bonusutbetaling, og dette må i alle fall være avgjørende.” I dommen kommer lagmannsretten frem til at bonus som er betinget av at en fortsetter i jobben etter skjæringspunktet, ikke skal være en del av delingsgrunnlaget. Det er begrenset hvor stor rettskildeverdi vi kan tillegge en enkelt lagmannsrettsdom, og den er eneste dommen som direkte omhandler dette temaet.

En grunnleggende premiss for lagmannsrettens argumentasjon i avsnittet ovenfor, er at retten ikke anser bonusen som ervervet ved skjæringstidspunktet. Hadde ektefellen sluttet i selskapet ved skjæringstidspunktet ville vedkommende ikke fått noen utbetaling. Dette kan brukes som et argument for at ektefellen ikke "hadde" bonusen ved skjæringstidspunktet. Hvis ektefellen ikke har ervervet bonusen ved skjæringstidspunktet, vil man kunne sammenlikne bonusen med verdistigning og/eller lønn som kommer etter skjæringstidspunktet. At ektefellen ikke hadde hatt krav på noe av bonusen om vedkommende sluttet i selskapet ved skjæringstidspunktet, taler for å ikke skille mellom disse tilfellene. At verdistigning og lønn etter skjæringstidspunktet skal holdes utenfor deling kommer frem av ordlyden i lovteksten.

I dommen avfeier lagmannsretten en anførsel angående den betingede bonusen: "I en situasjon som dette vil det alltid kunne hevdes at partenes fellesskap, og dermed også 
den andre ektefellens økonomiske og faktisk innsats for familien, er en medvirkende årsak til og forutsetning for at ektefellen kan inneha en stilling som setter ham eller henne i stand til eventuelt senere å oppnå en bonus etter en slik avtale. Men dette kan i seg selv ikke gi noe grunnlag for at bonus opptjent etter skjæringstidspunktet skal tas med i delingsgrunnlaget, like lite som annen verdistigning eller andre inntekter som kommer senere som hovedregel skal tas med.”. Lagmannsrettens argument gjelder inntjeningsevnen etter skjæringstidspunktet for ektefeller som skiller seg. Poenget er at inntektsevnen alltid kan sies å være påvirket av forholdene under ekteskapet, men at dette ikke bør medføre at fremtidig ervervsevne skal være gjenstand for deling. Dette argumentet støtter jeg. Det kan bl.a. vises til at det vil være vanskelig å avgjøre hvor stor del av fremtidig inntektsevne som skyldes forhold under ekteskapet. På den andre side kan det argumenteres med at ved en forholdsmessig fordeling så vil ikke fremtidig inntektsevne bli belastet, bare det en allerede har inntjent, og at det derfor ikke er noen motsetning mellom disse. Til dette kan det igjen anføres at om en forholdsmessig del av den betingede opsjonen skal deles, vil den ene ektefellen måtte dele midler som krever en innsats av vedkommende etter skjæringstidspunktet for å bli ervervet. Derfor vil en forholdsmessig deling av en betinget opsjon, medføre at en ektefelle indirekte blir belastet for fremtidig arbeidsevne.

Disse argumentene trekker i retning av at en opsjon ikke bør være gjenstand for deling, om man kommer til at den er betinget ved skjæringstidspunktet.

Det kan se ut som om lagmannsrettens syn får støtte i teorien, selv om ikke eksempelet er nevnt spesifikt. "Suspensivt betingede fordringer hvor betingelsen ikke er inntrådt, skal som hovedregel ikke deles, men her må det være rom for unntak. Hvor eiendel erverves hvis ektefellen gjør eller ikke gjør noe, vi ervervet i utgangspunktet skje når betingelsen er oppfylt.” ${ }^{25}$ Dette synet støttes av Lødrup (2005) (s 235), som mener Rt1978-1327 understøtter dette standpunktet. Jeg vil ta for meg høyesterettsdommens overføringsverdi litt senere i denne drøftelsen nedenfor.

Rettsteorien sier at det vil kunne være unntak fra regelen om at betingede fordringer ikke skal deles. Hva som skal til for at slike betingede fordringer ikke skal deles sies det derimot ingenting om. Av denne grunn er det vanskelig å si hva som skal til for at en

\footnotetext{
${ }^{25}$ Holmøy (2001) s. 408
} 
betinget fordring skal være gjenstand for deling etter el § 60. Underrettsdommen i felleskap med juridisk teori taler for at opsjonen skal holdes utenfor og må tillegges en viss vekt, uten at det vil ha sterk rettskildemessig vekt.

Det finnes argumenter for at opsjoner med bindingstid som ikke er utløpt ved skjæringstidspunktet skal være gjenstand for delingen etter el § 60. Det kan anføres at disse betingede fordringene har en økonomisk verdi ved skjæringspunktet, selv om det ikke er sikkert at de kan bli benyttet i fremtiden. Opparbeidingen vil som oftest til en viss grad være foretatt under ekteskapet. Det bør være mulig å beregne seg frem til en verdi av de betingede fordringene, som tar hensyn til risikoen for at de faller bort fordi betingelsene ikke blir innfridd.

Rettstekniske hensyn kan derimot tale for å ikke ta med betingede opsjoner på skifte. Det vil kunne være ressurskrevende å beregne en økonomisk verdi av disse. I tillegg blir resultatet mer usikkert, og det kan skape variasjoner i resultatet ved relativt like tilfeller, noe som er lite ønskelig. Det vil være enklere og mer stabilt å holde betingede fordringer utenfor.

Det kan anføres at hva en ektefelle "hadde” etter el § 60, bør avgjøres på samme måte som i el § 59. Reglene avgjør hva ektefellen hadde ved ekteskapsinngåelsen og ved skjæringstidspunktet. Det kan argumenteres med at reglene for hvordan dette avgjøres bør være like uavhengig om det gjelder inngåelsen av ekteskapet eller samlivsbruddet. Etter el $\S 59$ må det gjøres en forholdsmessig vurdering av en opsjon som var betinget ved ekteskapsinngåelsen, hvis den kreves skjevdelt.

Det står i forarbeidene til el §§ 58 og 59 at hensikten med delingsreglene er at ektefellene skal dele det som er ervervet ved innsats foretatt under ekteskapet, men ikke det hvor innsatsen er gjort før ekteskapet ble inngått. I forarbeidene til el § 60 er valget av samlivsbruddet som skjæringstidspunktet, begrunnet med at samlivet som begrunner likedelingsregelen da faller bort. Det virker her som at formålet med el § 60, er at det er de midlene hvor innsatsen ved ervervelsen er gjort mens samlivet besto som skal deles. Hvis dette er begrunnelsen for el § 60, vil dette være et hensyn for at det må gjøres en forholdsmessig vurdering av den betingede opsjonen på skiftet. Det er fordi en del av innsatsen er foretatt før samlivsbruddet og en del er foretatt etter samlivsbruddet. 
Behandlingen av goodwill ved familierettslige skifter vil kunne ha likhetstrekk med opsjoner og bonuser. Problemet med goodwill vil kunne oppstå når to ektefeller skiller seg, og den ene ektefellen eier et firma som er gjenstand for deling etter el § 60. Goodwill innebærer at firmaet har immaterielle verdier som for eksempel at en fast kundekrets benytter firmaet, renommé, erfaring, opparbeidet kompetanse ${ }^{26}$ o.s.V.. Ved verdsettelsen av næringsvirksomheten etter el § 69 skal goodwillen normalt regnes med, hvis den øker omsetningsverdien. ${ }^{27}$ Hvis goodwillen er knyttet til ektefellens person, for eksempel at den er avhengig av at ektefellen fortsetter å jobbe i firmaet, skal goodwillen ikke taes med i verdivurderingen. ${ }^{28}$ Dette begrunnes i teorien ${ }^{29}$ med at det er omsetningsverdien som skal legges til grunn, og at denne vil tilsvare slakteverdien hvis ikke ektefellen forplikter seg til å bli værende i stillingen, noe man ikke kan kreve. Det er videre i teorien og i forarbeidene argumentert med at hvis en trekker inn goodwill som avhenger av ektefellen personlig, vil dette innebære at ektefellen blir belastet for sin fremtidige ervervsevne. Dette bør unngås på prinsipielt grunnlag. ${ }^{30}$

Likheten mellom goodwilltilfellene som ikke skal ha betydning for verdivurderingen og opsjon/bonustilfellene, går i hovedsak ut på at begge er avhengig av at en av ektefellene må fortsette i arbeidet, for at de skal ha noen verdi. Argumentene som benyttes for at goodwillen som er knyttet til ektefellen ikke skal påvirke verdivurderingen, kan i stor grad benyttes for opsjoner og bonuser også. Hvis en opsjon som krever at en ektefelle skal bli værende i jobben et år etter skifte skal være gjenstand for deling, vil dette indirekte innebære at fremtidig inntektsevne deles. Dette fordi opsjonen krever at ektefellen fortsetter å jobbe i firmaet etter skjæringstidspunktet for at den skal få verdi.

Likheten mellom goodwilltilfellene og opsjons og bonustilfellene taler for at opsjoner og bonuser med bindingstid ikke skal være gjenstand for deling. Rettskildevekten av dette bør ikke tillegges for stor vekt, men overføringsverdien vil kunne ha betydning på et relativt åpent område som dette.

\footnotetext{
${ }^{26}$ Tidskrift for Norges legeforening (2007) s. 2285

${ }^{27}$ NOU 1987: 30 s. 141 , Rt. 1940 s. 536

${ }^{28}$ NOU 1987: 30 s. 141

${ }^{29}$ Lødrup (2005) s. 251

${ }^{30}$ Lødrup (2005) s. 251
} 
Rt-1978-1327 gjaldt et skifte hvor spørsmålet var om et lodd som hadde gitt en bilgevinst var gjenstand for deling. Spørsmålet ble løst ved at samlivet ikke var brutt da loddtrekningen foregikk. Det som imidlertid er interessant, er at Høyesterett tok utgangspunkt i når loddtrekningen foregikk og ikke når loddet ble kjøpt. Her kan det trekkes en parallell til opsjons og bonuseksemplet, hvor man heller ikke vet om det man har vil ha en verdi før på et senere tidspunkt. Denne dommen taler for at en ikke kan si at en ”hadde” en fordring etter el § 60 før den er ubetinget.

Det er forskjeller på loddeksemplet og opsjon og bonuseksemplene som minker overføringsverdien. I opsjon og bonuseksemplet vil man i større grad selv påvirke hvilken verdi opsjonen eller bonusen vil få. Det er tross alt en betydelig forskjell fra å være prisgitt en loddtrekning og i større grad kunne råde over utfallet selv. I tillegg vil sannsynligheten for at loddet gir gevinst være betydelig mindre, enn for at opsjonen eller bonusen har verdi. En kan ikke si at en eventuell gevinst er opptjent før trekningen er foretatt. Da får en heller se det slik at loddet ved en eventuell gevinst har hatt en betydelig verdiøkning. Likevel er det en viss sammenheng mellom et lodd man ikke vet om vil gi gevinst og en opsjon man ikke vet om vil kunne innløses, og Høyesterett kom til at det var ved tidspunktet man visste at loddet ga gevinst som var avgjørende for loddets verdi. Hvis en betinget opsjon skal avgjøres etter samme metode, vil dette medføre at opsjonen skal holdes utenfor deling.

Overføringsverdien fra loddeksemplet og til Opsjons- og bonuseksemplet er slik jeg ser det begrenset. Likevel vil det i sammenheng med andre relativt like tilfeller kunne tillegges en viss vekt i retning av at den betingede opsjonen skal holdes utenfor deling.

Hvis en fordring er usikker ved skjæringstidspunktet, vil det måtte gjøres en skjønnsmessig vurdering av fordringen. ${ }^{31}$ Et typisk eksempel er royalties av opphavsrettigheter. Ved skjæringstidspunktet vil man ofte ikke vite hvor store inntekter en slik avtale vil gi, men siden den foreligger ved samlivsbruddet skal den med på skiftet. En kan her se likhetstrekk med opsjons- og bonuseksemplet. Likheten i tilfellene består i at ikke hvor mye en vil få utbetalt. Siden det gjøres forholdsmessige vurderinger av royalties og opphavsrettigheter kan dette tale for å gjøre det samme med bonuser og opsjoner. Forskjellen på disse tilfellene er at ved de usikre fordringene er jobben gjort, mens det ved

\footnotetext{
${ }^{31}$ Holmøy (2001) s. 411
} 
fortsatt må arbeides etter skjæringstidspunktet i opsjons- og bonuseksemplet. Dette medfører at likheten mellom tilfellene blir mindre og følgelig også vekten av argumentet om at tilfellene skal behandles likt. Likevel vil likheten mellom fordringer av usikker verdi og bonuser/opsjoner til en viss grad kunne tale for at en forholdsmessig del av bonusen skal være gjenstand for en forholdsmessig deling.

Latente skatte-forpliktelser/fordeler (skriver hetteretter forpliktelser selv om det kan være begge deler)er ofte usikre. Ved skjæringstidspunktet vil en ikke vite om slike skatteforpliktelser vil bli aktuelle, og heller ikke når de eventuelt vil bli aktuelle. Vi kan se likheten mellom slike usikre skatteforpliktelser og en betinget opsjon. Det er for det første usikkert om noen av dem vil ha noen verdi. Videre vil ektefellen som har en latent skatteforpliktelse eller en betinget opsjon, selv ha mulighet til å påvirke verdien av dem. Ved opsjonen kan eieren som oftest velge å bli værende i jobb til den betingede opsjonen er ervervet. Ved latente skatteforpliktelser vil den som har forpliktelsen kunne råde over sine midler slik at vedkommende ofte kan avgjøre om skatteforpliktelsen skal inntre eller ikke gjennom sine handlinger. Likheten mellom latente skatteforpliktelser og betingede fordringer er et argument for at slike tilfeller skal behandles likt på skifte. Hvis det foreligger en latent skatteforpliktelse ved skjæringstidspunktet, så vil den i utgangspunktet være gjenstand for deling etter el § 60. Verdien må i så fall settes skjønnsmessig. Dette taler for at en opsjon som er betinget på skjæringstidspunktet skal være gjenstand for deling.

Det er en forskjell mellom eksemplene som minsker overføringsverdien mellom de to. Det er at det ved den betingede opsjonen kreves en innsats av den som har opsjonen etter skjæringstidspunktet for å erverve den. Ved latente skatteforpliktelser vil ikke ektefellens innsats etter skjæringstidspunktet gjøre seg gjeldene på samme måte. Ektefellen kan riktignok i en del tilfeller påvirke verdien av den latente skatteforpliktelsen ved sine handlinger, men det kreves ingen innsats for at skatteforpliktelsen skal gjøre seg gjeldende.

Overføringsverdien fra latente skatteforpliktelser er et hensyn som taler for at det må gjøres en forholdsmessig deling av opsjoner som er betingede ved skjæringstidspunktet. Forskjellen mellom eksemplene minker likevel overføringsverdien til en viss grad. 
Etter en helhetsvurdering av de rettskildene som er nevnt, har jeg under sterk tvil kommet til at den betingede opsjonen må holdes utenfor deling etter el § 60. Det avgjørende har vært at de fleste rettskildene, som i seg selv ikke har hatt så stor vekt, i fellesskap har talt for denne løsningen.

Det kan problematiseres om det ved tilfeller hvor det er lite igjen av bindingstiden, må kunne gjøres unntak fra regelen om at betingede fordringer ikke skal være gjenstand for deling. Dersom det er kort tid igjen av bindingstiden vil det kunne bli ansett som nærmest urealistisk at ektefellen slutter i jobb før bindingstiden er utløpt. Spørsmålet blir om dette i så fall kan vektlegges, slik at det kan gjøres unntak fra regelen om at opsjoner og bonuser som er betinget ved skjæringstidspunktet ikke skal være gjenstand for deling?

Hvis et ektepar for eksempel flytter fra hverandre 7.5.2008, og ektefelle A har en bonus med bindingstid som utløper 14.5.2008, vil det jo være liten sannsynlighet for at ektefelle A slutter i jobb i løpet av den siste uken før vedkommende har sikret seg en stor bonus. Det kan da virke som anstaltmakeri å si at det foreligger en betingelse ved bonusen i et slikt tilfelle. Vil det likevel bli ansett for å ligge en betingelse til bonusen, eller vil man her si at betingelsen er såpass hypotetisk at bonusen må være gjenstand for deling? Det kan jo fortsatt hende at ektefellen sies opp før bonusen utbetales. Hvis man er i oppsigelsesperioden vil en ofte miste retten til bonusen. I så fall vil det være urimelig at ektefellen må dele verdier den ikke har, og det vil være i sterk kontrast med lovens ordlyd.

Ved et skifte vil disse forholdene som oftest være klarlagt. En tanke som da melder seg, er å se hvordan det faktisk endte, om ektefellen ble værende i jobben ut bindingstiden eller ikke. Dette er ikke uproblematisk juridisk sett, fordi det som skjer etter skjæringstidspunktet skal være skiftet uvedkommende. Derfor vil det være begrensede muligheter til å ta hensyn til hva som skjer etter skjæringstidspunktet.

Det kan likevel tenkes at det som hender etter skjæringstidspunktet vil bli vektlagt i en rettstvist, uten at det nevnes uttrykkelig. Dette kan imidlertid gjøre seg gjeldene begge veier. Hvis en åpner for å dele bonuser eller opsjoner hvor bindingstiden utløper kort tid etter samlivsbruddet, vil nok ikke bonusen bli gjenstand for deling hvis en ser at ektefellen sluttet før bindingstiden til bonusen var utløpt. 
Hvis det er mulig å gjøre unntak for de tilfellene hvor det er kort tid igjen av bindingstiden vil man til en viss grad unngå terskeleffekten, men en slik løsning er likevel ikke problem fri. Det vil uansett måtte gjøres en grensedragning om hvor lite av bindingstiden som skal gjenstå for at det skal kunne gjøres unntak. Et eller annet sted vil det måtte settes en grense. Ved å ha en absolutt grense, slipper man tvilstilfeller som skaper tvist. I tillegg er det som nevnt før ikke uproblematisk å ta hensyns til hvordan utfallet av en betinget fordring blir etter skjæringstidspunktet.

Jeg er kommet til at det ikke kan gjøres unntak fra regelen om at opsjoner og bonuser som er betinget ved skjæringstidspunktet.

La oss ta utgangspunkt i et nytt eksempel med en bonusbankavtale, for å se om denne bonusordningen må behandles annerledes enn de vanlige ordningene ovenfor. Ektefelle A har ved samlivsbruddet i februar 2008 en bonusbankavtale hvor saldoen er 1800000 kroner. Det skal hvert år utbetales 1/3 av saldoen, og det er et krav at ektefelle A blir værende i jobben. Noe som vil innebære at hvis det ikke overføres midler til bonusbankkontoen, vil det i år 2009 utbetales 1/3 av 1800000 (600 000) og i år 2010 1/3 av 1200000 (400 000) osv. Eksemplet er basert på typetilfellet i punkt 3.3 (bonusbankeksemplet).

Igjen vil spørsmålet være om det kan sies at ektefellen hadde midlene ved skjæringstidspunktet etter lovens ordlyd. Er det noen grunn til å behandle dette spørsmålet annerledes enn opsjons- og bonuseksemplet ovenfor?

Ved dette eksemplet vil ektefelle A ha en viss økonomisk fordel av saldoen som er opptjent under ekteskapet hvert år etter samlivsbruddet, men kan en si at ektefellen har verdien av bonusbanksaldoen ved skjæringstidspunktet? Hvor mye ektefellen vil få av bonusbanksaldoen vet en jo ikke, fordi den er avhengig av at ektefellen jobber der. Siden det som skjer etter skjæringspunktet skal være skiftet uvedkommende, vil saldoen i bonusbankeksemplet ikke kunne være gjenstand for deling. De samme argumentene som er nevnt i eksemplet ovenfor vil også gjøre seg gjeldene for dette eksemplet, og det er ingen grunn til å behandle de to eksemplene forskjellig. Begge tilfellene er avhengig av at ektefellen forsetter å jobbe i samme selskap etter skjæringstidspunktet, og det er dette som 
blir avgjørende. Derfor vil betingede bonuser i bonusbanktilfellene heller ikke være gjenstand for deling etter el § 60 .

Det kan spørres om løsningen kan bli annerledes enn ved de to ovenfor nevnte eksemplene hvis bindingstiden er lengre enn opptjeningstiden. En ektefelle har for eksempel en bonus hvor opptjeningstiden varer fra 1. januar 2007 til 31. desember 2007, men hvor bindingstiden løper frem til 15. mai 2008. Samlivsbruddet skjer 1. mars 2008. Vil det her være noen grunn til at et slikt tilfelle skal behandles annerledes? (eksemplet er hentet fra typetilfellet i punkt 3.2, der det kalles meglereksemplet)

Opptjeningsperioden er her forbi, men det kreves fortsatt at ektefellen blir værende i jobben etter skjæringstidspunktet. Det som har vært avgjørende for resonnementene ved de andre tilfellene har ikke vært opptjeningstiden, men bindingstiden. At bonusen eller opsjonen er betinget, er årsaken til at den ikke er gjenstand for deling. Siden bindingstiden her ikke er utløpt, vil bonusen fortsatt være betinget og følgelig vil den ikke være gjenstand for deling selv om opptjeningsperioden er utløpt.

Etterpådaterte opsjoner kan også medføre tvister ved skifte etter el § 60. Vi går ut ifra at ektefelle A har en opsjonsordning som gir rett til å kjøpe aksjer i firmaet til kursen ved inngåelsen av opsjonsordningen. Reelt sett inngåes avtalen i desember 2004 og varer frem til desember 2007, mens den på papiret blir inngått i juni 2005 og varer til juni 2008. Vi går ut ifra at ektefellene bryter samlivet i mars 2008.

Årsaken til at de setter datoene annerledes enn det som er reelt, er for å øke verdien av opsjonen. Derfor flyttes enten datoen som bestemmer hvilken kurs opsjonen skal kunne innløses til, til en dato hvor kursen var lav, slik at en betaler lite for å kjøpe aksjene gjennom opsjonen. Ellers flyttes datoen opsjonsavtalen utløper til en dag hvor kursen var høy, slik at aksjene en kjøper gjennom opsjonen kan selges til en høy pris. Eksemplet er en spesiell utgave av opsjons og bonus typetilfellet i punkt 3.1.

Det kan her spørres om det er den reelle eller den formelle tidsperioden som skal legges til grunn når dele skal foretas. Det sentrale her blir om datosettingen innebærer at bindingstiden forandres. Hvis bindingstiden utvides til å vare frem til juli 2008, så vil ikke 
opsjonen være gjenstand for deling. Hvis den derimot ikke er betinget av at vedkommende jobber der, vil svaret måtte bli at opsjonen skal være gjenstand for deling. Problemet med antedaterte opsjoner i forhold til el § 60 vil være om flyttingen av datoene påvirker bindingstiden. Hvis de gjør dette vil, det kunne påvirke skiftet, og hvis det ikke gjør det, må de reelle datoene være avgjørende. Dette vil i praksis ofte kunne munne ut i et bevisspørsmål om hvordan forholdene er.

\subsubsection{Hvordan beregne en eventuell forholdsmessig del}

Hvis en subsidiært skulle ta utgangspunkt $i$ at en forholdsmessig del av en opsjon eller bonus, som er betinget ved skjæringstidspunktet, skal være gjenstand for deling, vil det kunne problematiseres hvordan den forholdsmessig delen skal avgjøres. Den forholdsmessige delingen, vil måtte utmåles etter hvor stor del av bindingstiden som løp før og etter skjæringstidspunktet, uavhengig hva slags opsjon eller bonus som foreligger.

Som eksempel kan vi bruke en bonusordning som varer fra 1. januar 2008 til 31. desember 2008. Ektefellene bryter samlivet 1. juli 2008. Det som skal deles er det ektefellene hadde ved dette skjæringstidspunktet (el § 60). Hvis ektefellen blir ansett for å ha halve bonusen ved samlivsbruddet, er det denne halvdelen som skal være gjenstand for deling. Det kan ikke tas med en større del, fordi dette ville stride mot ordlyden i el § 60 . Dette ville medføre at ektefellen ville blitt belastet for fremtidige inntektsmuligheter, noe som er lite ønskelig.

Det må videre gjøres en verdsettelsesvurdering av den halve bonusen. Etter el § 69

1. og 2. ledd er det omsetningsverdien ved skjæringstidspunktet som skal legges til grunn for verdsettelsesvurderingen.

Hvis en betinget bonus skal være gjenstand for deling må en altså først finne den forholdsmessige delen som ektefellen "hadde" ved samlivsbruddet, og så finne omsetningsverdien av den forholdsmessige delen ved skjæringstidspunktet. 


\section{Litteraturliste}

http://www.uio.no/studier/emner/jus/jus/VALSPE10/

Holmøy, Lødrup 2001 Ekteskapsloven

Lørdrup, Sverdrup 2004 Familieretten

Lødrup Peter 1962 Rettspraksis omkring ekteskapslovens § 54, 4. ledd

Eeg 2006 deling av ektefellers formuer

Bøhren, Øyvind og Michaelsen, Dag (2006): Finansiell økonomi: teori og praksis, Bærums Verk: Skarvet forlag

Statistisk sentralbyrå - Bonus - hvor mye og til hvem? ISBN 978-82-537-7190-8

Elektronisk versjon. Harald Lunde og Knut Håkon Grini.

Thoresen, Hilde (2001):”Opsjoner i arbeidsforhold”, Makt og demokratiutredningen 1998 2003, nr 27, januar 2001 
Nettadresser:

Makt og demokratiutredningen - nr 27 - opsjoner i arbeidsforhold

http://www.sv.uio.no/mutr/publikasjoner/rapp2001/Rapport27.html

Steingrimsen Tonje 2006 opsjoner et effektivt virkemiddel for å tiltrekke, binde og motivere til innsats?

http://bora.nhh.no/bitstream/2330/1664/1/Steingrimsen\%20Tonje\%202007.pdf

Lederlønninger og opsjoner - en utredning av Jon Gunnar Pedersen:

http://www.regjeringen.no/upload/kilde/nhd/nyh/2006/0089/ddd/pdfv/300892-eierskap06-

lederlonnopsjoner.pdf

opsjonsskole oslobørs

http://www.oslobors.no/servlet/BlobServer?blobtable=Document\&blobheader=application

\%2Fpdf\&blobwhere=1045746725270\&blobcol=urlblob\&blobkey=id\&1045746725270.pdf

NHO veiledning: Er bonus lønnsomt? 2006

http://www.nho.no/files/DM-59020-v1-Veiledning_bonus.pdf

Wikipedia, Options backdating

http://en.wikipedia.org/wiki/Options_backdating

Kongsberg Gruppens bonusbank system

http://www.kongsberg.com/nor/kog/Investorinformasjon/Rapporter/Rapporter2006/nor/not

es_group/group_note30.asp

Tidskriftet for Norges legeforening (2007) nr. 17

http://pdf.tidsskriftet.no/tsPdf.php?pdf=pdf2007\%7C2285.pdf 
Bråta Øystein 2006, Økonomiske styringsverktøy i Kongsberg Automotive Holding ASA - en helhetlig analyse av et styringssystem

http://bora.nhh.no/bitstream/2330/461/1/Brata\%20Oystein\%202006.pdf 


\section{Lister over tabeller og figurer $\mathbf{m} \mathbf{v}$}

http://www.uio.no/studier/emner/jus/jus/VALSPE10/ 